\title{
دراسة تحليلية لأمكانات والموارد المتاحة للسياحة الرياضية بجنوب الصعيد
}

\section{*احث/ محمد علاء الاين محمدعبد المنعم مكي}

\section{مقدمة ومشكلة البحث}

تعتبر السياحه نشاط بشري يقوم على استغلال الموارد الطبيعيه والبيئيه المتتوعه واستثمارها لخدمه انشطه ورغبات السائحين و تحقيق اكبر قدر للاستفاده دون الاضرار بتلك الموارد كما ان السياحه تقوم على دراسه الثقين الطبيعي والبشرى وكيفيه الربط بينهما حيث انهم يمثلون الدعاء من النشاط السياحي ونجد ان التنقل والحركه يعتبر من الخصائص الانسانيه ، فقد داب الانسان منذ نشاته على الانتقال من مكان الى اخر سعيا وراء لقمه العيش ثم سعيا وراء تحقيق المتعه النفسيه والذهنيه بعد ذلك تحولت عمليه النتقل مع الايام الي ظاهره ذات ابعاد مختلفه في المجالات الاقتصاديه والاجتماعيه والثقافيه .

وتتميز مصر بتتوع مواردها السياحية التي تعتمد على إمكانات تاريخية وثقافية ودينية وجغرافية، لذا تعتبر السياحة مصدراً هاماً من مصادر ألدخل القومي المصرى، وإدراكاً للدور الذى يؤديه هذا القطاع تعمل الدولة على زيادة عدد الليالى السياحية إلى مصر والاستفادة من الاقامات الرختلفة ومنها الاقامات الرياضية وذلك عن طريق ما بسمى بالسياحة الرياضية حيث بسعى هذا الاتجاه الحديث الى تسويق البرامج السياحية داخل مصر عن طريق الرياضة أو تسويق بعض المسابقات الرياضية الحديثة مثل مسابقات الجولف والاسكواش والألواح الثراعية عن طريق السياحة.

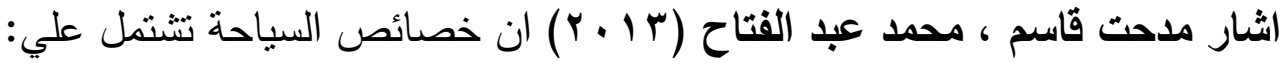


- المناخ السياحي يعتبر من العوامل المؤثرة علي المنتج السياحي ويرتبط بالكثثر من الانشطة الاقتصادية

- ارتباط صناعة السياحة بقضايا التتمية الاقتصادية والسياسية في كثثر من الدول وخاصة النامية

- يتاثرالطلب السياحي بمسنوي الرفاهية الاقتصادية والتقام التكنولوجي والعوامل الثقافية والسياسية التي يصعب علي الدول التحكم فيها.

- تتعد وتتتوع السياحة واغراضها مما يترتب علية اختلاف الانشطة وطبيعة الخدمات السياحية المرتبطة ( قاسم،عبدالفتاح : r ا ( )

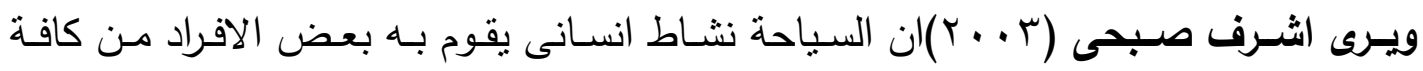

الطبقات الاجتماعية بدافع شخصى بهدف قضاء وقت الفراغ والتزويح (صبحي : • (1) أمسا وزارة السـياحة المصـرية فقد عرفتها على أنها عمليـة الانتقال والإقامـة التى يقوم بها الإنسان من موطن أقامته المعتاده الى موطن أخر وبصفة مؤقتة ولغير أغراض الكسب المادى شريطة ألا تقل مدة أقامته عن ع ب ساعة. ( وزارة السياحة: 1 ) ) ويشير صـلاح عبد الوهـاب إلى انهـ يمكن النظر الى السياحة فى صورتها المجردة على أنها ظاهرة اجتماعية تتضمن انتقال الإقراد من المكان المعتاد لإقامتهم الى أماكن أخرى داخل دولهم

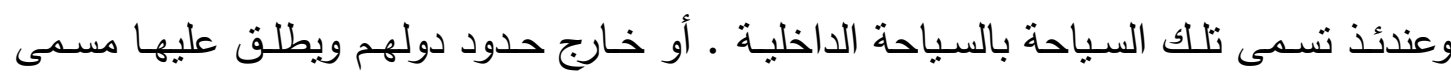

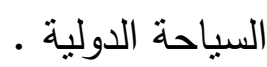

وبوجة عام فأن الوصف الدولي لمصطلح السياحة الدولية والمتفق علية بين الدول هو "عبور شخص ما للحدود الدولية لبلاده الي بلد اخر ليمكث به مدة محددة ولاغراض غير مهنية". 
ومن الاستعراض السابق يري مدحت قاسم واحمد عبد الفتاح r ( • بم السياحة بأنها وسيلة جيدة

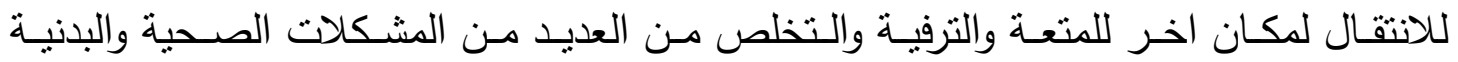
والنفسية.

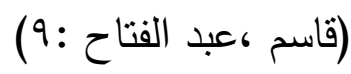

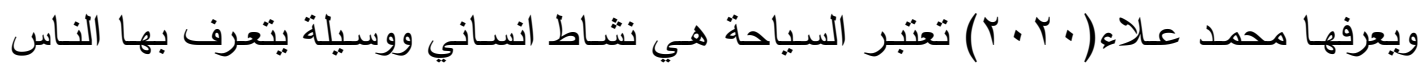
بعضهم علي بعض، وهي احد العوامل الرئيسية للمتعـة والسياحة هي علم وفن وعمل لجذب

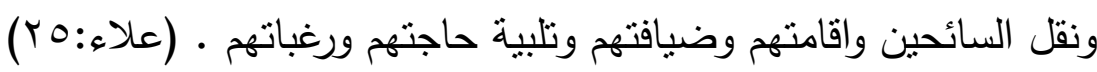
من خلال ما سبق يتضح انه قد توالت المحاولات العديدة لتعربف السياحة من اتجاهات مختلفة (اجتماعياً - سياسياً - اقتصادياً ) · ولكن كل التعاريف اتفقت على أن السياحة لها جانب معنوي وهو أقامة العلاقات وجانب مادى اى مردودها سواء اقتصادى أو سياسى أو اجتماعى •

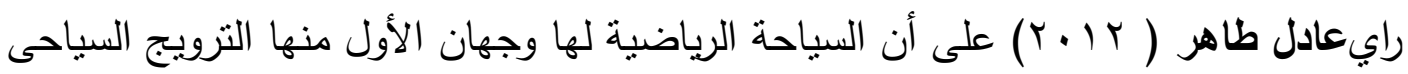
فى مواسم ركوده ، والآخر التنشيط لرياضة معينة واستخلالها فى هذه المواسم الراكدة سياحيا وجذبا لهواة هذه الرياضات للإشتراك فيها وممارسة ما يحبون بالإضافة إلى إتاحة الفرصة لهم لمشاهدة الأماكن التى تعد مزارا سباحيا لمزيد من الزيارات المستقبلية بما يعدونه لهذه الأماكن من إنشاءات استغلالها لموقع طبيعى ، أو أثز تاريخى أو ما شابه ذلك مما بدعم الحركة السياحية بجوار دعم الحركة الرياضية ـ (طاهر :؟0)

ويعرف مـاهر عبد الخـالق السيسـي (10 ب ب) نقلا عن الوصـف الـدولي لمصطلح السـئح والمعترف بـه هو : زائر مؤقت يقضى فى البلد الذى يزوره (عاب) سـاعة على الأقل ويكون الهدف من زيارته : 
- ـ الراحة والاستجمام أو قضاء وقت الفراغ فى الاجاذات أو العطلات بغرض الترويح أو ممارسـة مناشط الرياضة أو الدراسة أو العلاج ، العمل أو زيارة للأهل أو للأقارب أو للأصدقاء أو مقابلة الوفئ

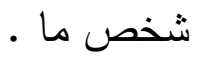

ويذكر ماهر عبدالخالق (10 • r م) الانماط السياحية : (الحديثة) سياحة المعاقين (ذوي الاحتياجات الخاصة )

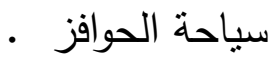
سياحة المشاركة في الوقت. السباحة البديلة والطبعية .

سياحة الاهتمامات الخاصة وتتضمن سياحات عديدة منها:

- السياحة التعلمية .

- سياحة الصحاري والوحات -

- سياحة الجولف .

- سياحة اليخوت .

- سياحة كبار السن (المسنين)

- سياحة الفرشات .
- - سياحة مراقبة الدلاقين والحيتان.

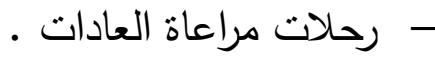

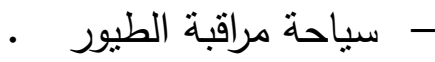

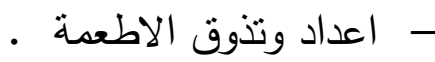
- - سياحة مشاهدة الاثار الغارقة ( سياحة اثريات ما تحت البحار ) . - رحلات حركة التجارة القديمة - سياحة الدرجات .

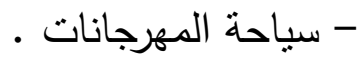
- سياحة بيوت الاقامة . (0)، (عبدالخالق السيسي :0r)
- رحلات التصوير ل - السياحة الطبعية . - السياحة البدائية .

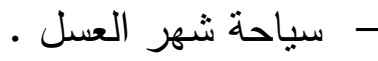

وعن عوامل الجذب السياحى كانت أهم النتائج مايلى : - مناطق الجمال والمناظر الطبيعية . 
- التسلية والتزفيه والرياضة . - الأحداث الاجتماعية والتعليمية . - المشاركة فى النشاطات الخارجية الترفيهية كالجولف والتتس . - الجذب الاجتماعى والمعنوى مثل زيارة الأصدقاء والأقارب . - اكتشاف النفس والتامل والاسترخاء - الحاجة الي البتعاد عن التوتر والضغط .

- الراحة والاستجمام والاستشفاء - البحث عن الجديد الي يضيفة الفرد لمعارفه

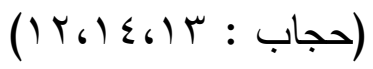

عناصر الجذب السياحى:- العنصر المكانى : وهو الموقع أو المنطقة المراد الذهاب أليها ـ العنصر الوظيفى : وهو السفر والإقامة .

( وهذان العنصران يمثلان المجموعة الكمية من الحركة السياحة ) . - العنصر الترويحى : يعبر عن المتعة ( الراحة والاستجمام ) .

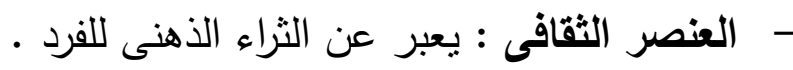
( وهذان العنصران يمثلان المجموعة النوعية من الحركة السياحية ) (عبدالمقصود:

جودة الخدمات السياحية: تضمن اعلان المانيا عن السياحة العالمية عام •9191 معالجة لتحسين جودة العرض السياحي كما يلي : ان تحسين مستوى جودة العرض السياحي ، الذي يؤدي بدورة الى احترام المستهلك وهو هدف

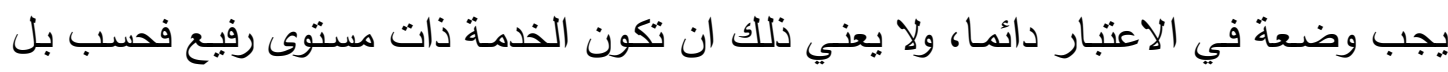
يجب ان تكون التسهيلات السياحية مخططة تخطبطا دقيق مع الاخذ في الاعتبار طبيعة الطلب لكي يمكن ضمان اتاحة السياحة بنوعية الدولية و الخارجية.. لشرائح اكبر من السكان وفي ذات الوقت الحفاظ على مستوى جودة هذة التسهيلات . 
يمكن تعريف الجودة : بانها ارتفاع الخدمة السياحية الى المستوى المتوقع من السائحين ، و يجب النظر الى الجودة على انها رضـاء العمـلاء والعـاملين معـا و هـي السبيل المؤكد لرفع الانتاجية وزيادة الدخل في المنشات السياحية بوجة عام. - الجودة ...لا تعني زيادة الكمية للخدمات (Quantity) او الخدمة العالمية الممتازة (deluxe) ولكن تعنـي (quality) موائمـة الخدمـة للمقاييس المحددة اوالملائكـة للسـعر اوالقيمـة المناسبة والمواجهة للاسواق المعنية و هي تعظيم رضا السائح •

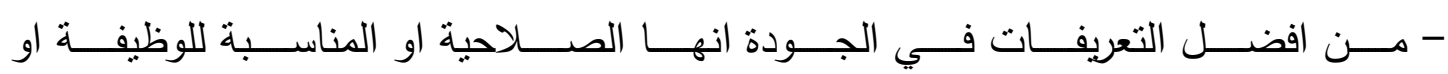
الغرضfitnessforpurpose والهدف من ادارة الجودة هو ( افعالها صحيحة من اول مرة و كل

(Do it right firs and everytime )

- وتعرف المنظمـة السياحية العالمية: جودة السياحة بانها نتيجة لعملية تتضمن تلبيـة جميع احتياجات المستهلك ومتطلباتة وتوقعاتة المشروعه من المنتجات والخدمات بسعر مقبول بحيث تكون مطابقة مع الثروط التعاقدية المتفق عليها ومحددات الجودة المشمولة بذلك مثل( السـلامة -الامن - الصحة -النظافة سهولة الوصول -الثفافية - الاصـالة- تجانس النشاط السياحي المعنى مع بيئنه البشرية و الطبيعية)

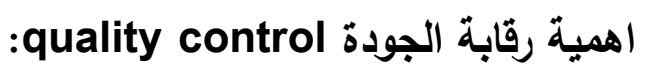

كانت اجهزة السياحة القومية وموارد الخدمات السياحية الى عهد قريب لا يعنوا تماما اهمية رقابة الجودة في المنتجات والخدمات السياحية و كانوا يعتقدون ان هذة الرقابة هي نوع من التفتيش.

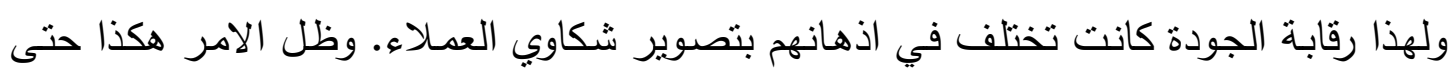
ظهـرت في الولايـات المتحـدة الامريكيـة و في الـدول الاوروبيـة الغربيـة تشـريعات حمايـة

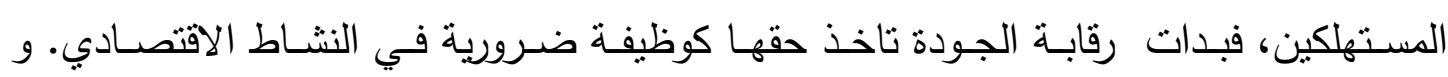
اصبحت رقابة الجودة من اهم خصائص انتظام الخدمات السياحية وضمانة من ضمانات اشباع رغبات السائحين وتحقيق رضاهم.

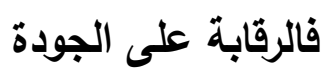


تعني (وسائل واسـاليب تتبعها الادارة العليا او التتفيذيـة) لتصـل لهدف معين فاذا كان الهدف (الجودة) فيجيب ان يكون هنالك: "معاير لهذة الجودة وتتبلور في صورة تعليمات تتفيذية وتحديد ما يجب عملة تجاة تجاوزات هذة المعايير مع مراعاة التحسين المستمر دائما" وتاخذ رقابة جودة الخدمات الاشكال و الاجراءات التالية: الملاحظة المباشرة للقيام بتتفيذ الخدمة السياحية.

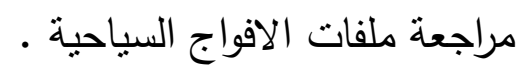
التقارير عن تتفيذ الخدمة السياحية. - - تقنيش واختيار المواد والمستلزمات المستخدمة في تقديم الخدمة قبل الاستلام وفي اثتاء التخزين

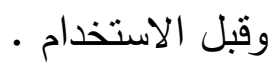

ان التسويق للخدمات السياحية يمنل اكبر صعوبة من التسويق لاي منتج او سلعة مادية اخرى

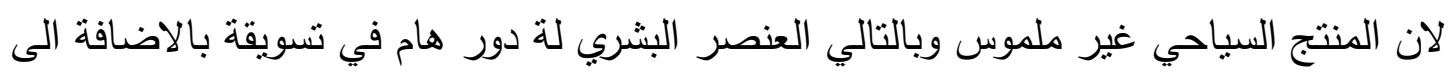
انة نشاط تخطيط وتتفيذ البرامج السياحية وتتظيم الرحلات الثاملة بتطلب قدرات خاصـة.. ولهذا فان عدم تتفيذ الثركة لبرامجها السياحية ورحلاتها الثاملة بالثكل الذي يتوقعة السائح سيؤدي الحى عدم رضـاء السـائح، وبالتالي لن يستمر في تعاملة مـع الثـركة السياحية او حتى يغير

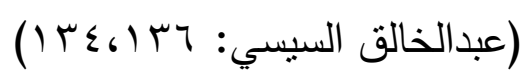
• مقصودة السياحي

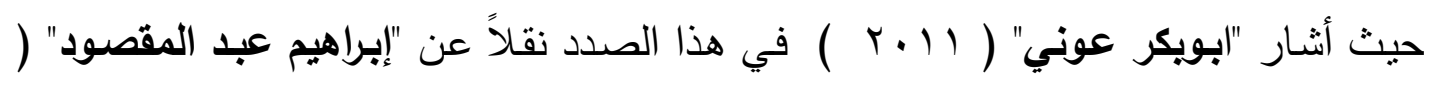
ـ . . r ) إلى أنـه في الوقت الحاضر لم تعد السياحة، تقتصر على زيارة الآتار القديمة التي خلفها الأجداد، لكن بدأ هنالك اتجاه عالمي جديد لربط السياحة بالرياضـة، بما يحقق خدمة كلا منهما للآخر ، فأغلبية الناس يفضلون قضاء الأجازات، ووقت الفراغ في ممارسة أوجه النشاط الرياضي في الدول المتقدمة.(عوني: 0 1) (عبد المقصود:^^ ع)

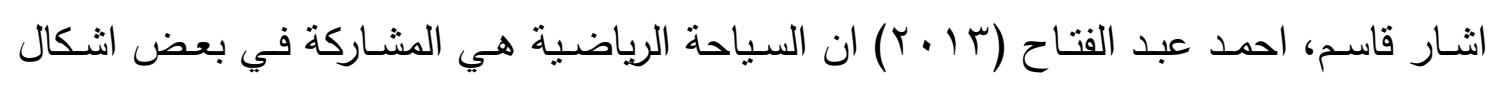
الرياضـة علي اسس الصداقة والمحبة وتتميـة العلاقات كالذي يحدث عند زيارة مكان اللعب او لوناه 
لمشاهدة افراد يلعبون وهنا يكون الاستمتاع بالمشاركة او بالمشاهدة وتعتمد السياحة الرياضية علي

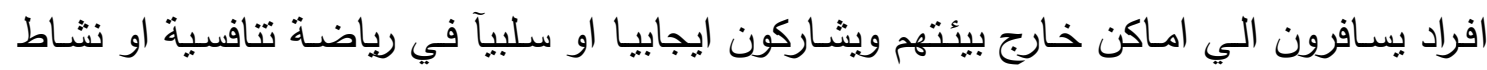
ترويحي ، فالسياح الذين بستخدمون الرياضـة يمكنهم تتظيم رياضـة تتافسية اوغير تتافسية مثال

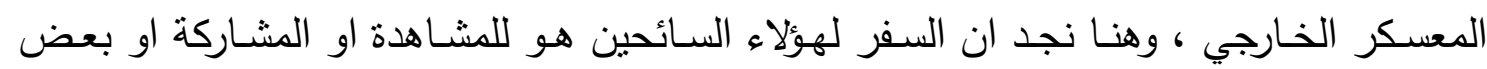
الالعاب ، ولذلك فالرياضة ستكون عنصرا اساسيا في اجازتهم ، والسياحة الرياضية نشاط رياضي هوني وهي اتتطة منظمة ،منل الجولف ،والتزحلق وسباق الخيل في حين انشطة اخري يمكن تصنيفها علي انها انشطة مغامرة منل سباق القوارب وتسلق الصخور .(قاسم:عبدالفتاح:9 س، ؟ ) يذكر "يسرى دعبس" ( • 1 • rم) أن السياحة الرياضية تعنى إثباع رغبات السـائحين فى ممارسة رياضتهم المفضلة سواء عن طريق استغلال عناصر الطبيعة مثل الإنزلاق على الماء والتجديف أو صبد الأسماك والحيوانات البرية والغطس تحت الماء والتزحلق على الجليد أو تسلق

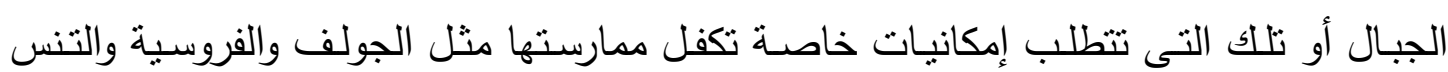
ورحلات السفارى والتخييم فى الغابات والصحارى •

ولاتقتصر السياحة الرياضية على مسـاهمة السـائح فى النشـاط الرياضـى بنفسـه ، بـل تمتـد إلى

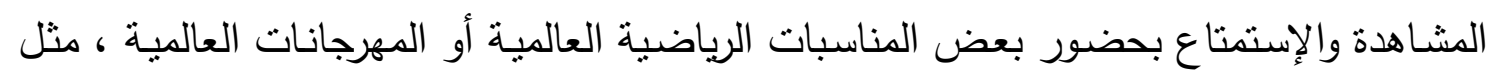
مباريات كأس العالم لكرة القدم والدورات الولمبيـة وكذللك الدورات الإقليميـة مثنل الدورة الإفريقيـة والدورة الأوربية لكرة القدم

(دعبس:O1،

ويشير "أحمد سعد الثريف" ( . . . Pم) إلى أن فلسفة السياحة الرياضية تعتمد على توجهين الأول الترويح السياحى ، فى مواسم الركود ، اما الآخر فهو التتشيط لرياضة معينة واستغلالها فى هذه المواسم الراكدة سياحيا ، وبالتالى استقطاب هواة هذه الرياضات للمشاركة فيها لممارسة ما يحبون ، بالإضافة إلى تتظيم رحلات خاصة لزيارة الأماكن السياحية التاريخية لمزيد من 
الزيارات المستقبلية ، وبما يعزز مفهوم السياحة الرياضية مع الأخذ فى الإعتبار ظروف المناخ للمشاركين

\section{إمكانات السياحة الرياضية :}

السياحة الرياضية هـى احد دعامـات الصناعة الحديثة ولابـد ان نوليها الاهتمـام الكافى حتى نسنطيع ان نجنى ثمارها ويرى الباحث انه ليكون المكان بمثابة مقصد سياحى يجب إن يجذب المكان الناس الذين يسافرون بعيداً عن منازلهم ليثـاهدوا أثشياء جذابة أو ليستخدموا الإمكانات وفى اغلب الأحيان يكون استخدام الإمكانات شيئاً ضرورياً للغاية لذلك تحاول الدولة ان تقوم بتوفير كافة الإمكانات اللازمة لممارسة مختلف أنواع الرياضة من ملاعب وأماكن أقامة وغيرها

وتقسم إمكانات السياحة الرياضية الى نوعان هما :-

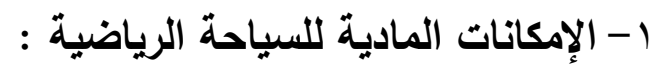

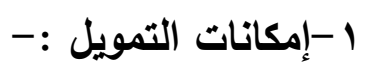

وهـى التـى تتعلق بتمويـل المشـروعات السياحية الرياضـية ( كـالبطولات والمناسبات الرياضـية والجوائز التى تمنح بها ) مما يضـع تلك البطولات فى مصاف البطولات العالمية وكذلك العمل على جذب الاستثمارات العالميـة للاستثمار فى مجال السياحة الرياضية وأعداد الإمكانـات أللازمة لها . 


\section{r}

وتتعلق بالمنشأت السياحية والرياضية من قرى رياضية منكاملة بالمناطق القريبة من المناطق السياحية، الفنادق المجزة بالإمكانات الرياضية وأماكن الترفيه والترويح.

\section{r - بالإمكانات الخاصة بالأدوات والاجهزة :}

وهى تتعلق بالأدوات الرياضية وأجهزة التدريب وأماكن صيانتها وتخذينها للحصول على اكبر استفادة منها.

ع -الإمكانات الخاصة بالأعلام والتسويق :

وتتعلق بالإعلان عن المناسبات الرياضية والتسويق الجيد لها حتى نستطيع من خلالها الحصول

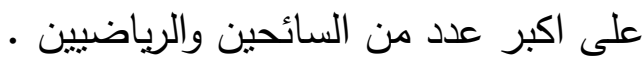
ه - الإمكانات البيئية الطبيعية :

وتتعلق بالمناطق الأثرية والجبال والصحارى والثواطئ وما الى ذلك من طبيعة متميزة ومتفردة والعمل على الحفاظ عليها والاستفادة منها بشكل افضل يحقق تميز للسياحة الرياضية المصرية

r الإمكانات البشرية للسياحة الرياضية : العاملون فى مجال السياحة الرياضية :- الإهية وهم كافة الأخصائيين العاملين بالمجال ونوعية تدريبهم واعدادهم وتخصصهم وعلى من يجب

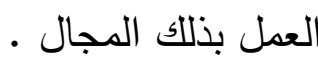

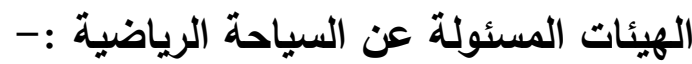
ويتعلق ذلك بالهيئات الرسمية وغير الرسمية التى يرتبط عملها بالسياحة الرياضية وتحقيق النجاح لها

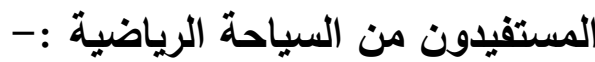
تستقيد الدولة بكامل هيئاتها وأفرادها من جراء السياحة الرياضية وتعود بالنفع على كافة الجهات .

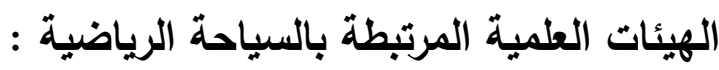


وهى كافة الجهات التى يجب عليها العمل على أعداد الأخصائين وحسن تدريبهم وإعدادهم بصورة منميزة قادرة على تحقيق النجاح للسياحة الرياضية (الحشاش: 9 (IV،

كمـا أن السـياحة الرياضـية أثتتـت نجاحها علـي مسـتوى العـالم وفي مصـر مثنل بطولـة الامـم

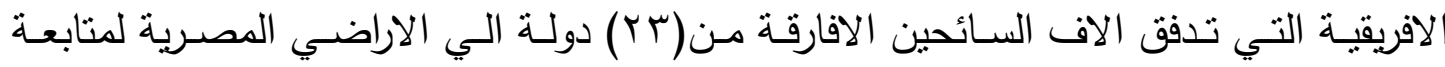
منتخبات بلادهم وايضا شهدت محافظة البحر الأحمر على مدى الثهور الماضية الكثير من الثن البطولات الرياضة العالمية على أرضها، وتحولت بالفعل إلى قبلة للرياضيين العالميين والبطولات الرياضية، حيث تم تتظيم أغلبية تلك البطولات على أرض الغردقة منها بطولة العالم للبلياردو

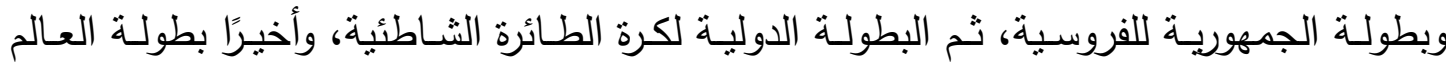
للألواح الثراعية .وانطلقت بطولة العالم للالواح الشراعية بمنطقة سوما باى واستمرت لمدة ل أيام ، ويشارك في البطولة أكثر من • 1 دول منها: 》ألمانيا، النرويج، إسبانيا، النمسا، سلوفاكيا، بهاء

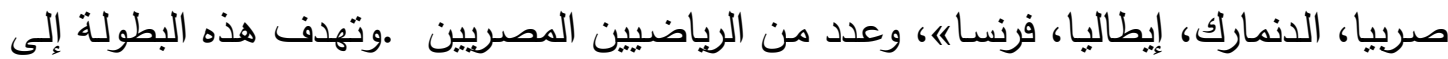
تسليط الضـوء على محافظـة البحر الأحمر ومنطقة سـوماباى تلك لمنطقة السـاحرة التي تقع منع جنوب مدينـة الغردقة، وهى منطقة مناسبة لهذه الرياضـات البحريـة، وذلك لمـا تتمتع بـه من مناظر خلابة وطبيعة ساحرة، كما تهدف البطولة إلى جذب العديد من رواد هذه الرياضـة إلى البحر الأحمر والاستمتاع بممارستها في هذه المنطقة .وفي نفس المنطقة "سوما باى" شهدت إنى

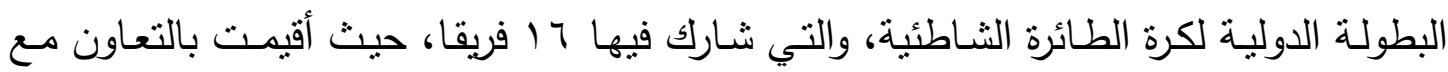
الاتحاد الألماني للعبة ومكتب تتشيط السياحة بألمانيا، وتمت تغطيتها إعلاميا بواسطة مجموعة من القنوات العالمية في مقدمتهم قنوات SKY التليفزيونية،حيث ان الرياضة والسياحة" علاقة لا تتنهى.. الأمـاكن الأثربـة سـلاح النجاح للبطولات فى مصـر .. اتحاد الكرةالطائرة يروج لبطولـة

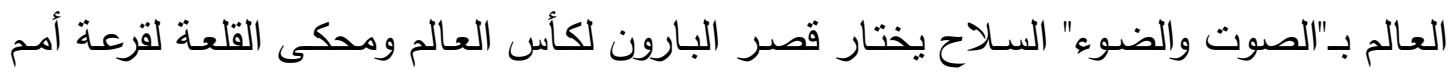
أفريقيا للبد 
العديد من ذلك الامـاكن مصر شهدت نجاحا كبيرا ، فى ظل إقامة منافسات الأدوار النهائية

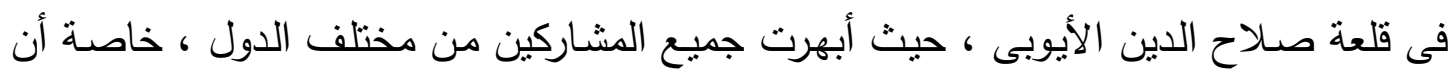

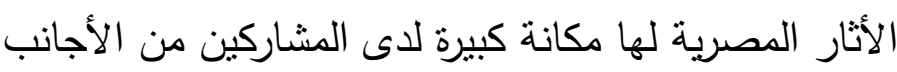

كما أن بطولة كأس العالم لسلاح الثيش التى أقيمت أكتوبر 1 ا ـ ب فى مصر شهدت نجاحا كبيرا ، فى ظل إقامة منافسات الأدوار النهائية فى قلعة صلاح الدين الدين الأيوبى ، حيث أبهرت جميع المشاركين من مختلف الدول ، خاصة أن الأثار المصرية لها مكانة كبيرة لدى المشاركين

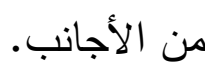

إختار مسئولو إتحاد السـلاح برئاسـة تامر زين العابدين قصر البارون لإحتضـان نسخة كأس

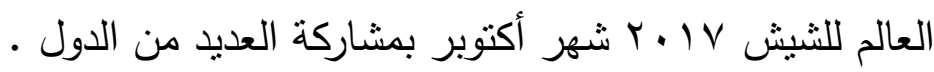

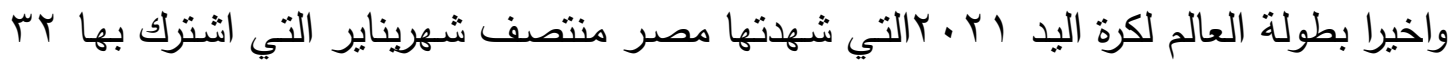
فريق من rr دولة من دول العالم لاول مره بعد ان كانت ؟r فريق فقط شهدت نجاحا كبيرا في ظل ازمه كرونا حيث ابهرت العالمن من حيث التتظيم والاجراءات الاحترازية

ومـن خـلال خبرة الباحث وعملـة كحكم بالعديد مـن الاتحـادات الرياضية منهـا اتحاد(الكانوي

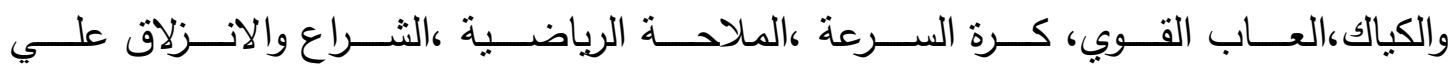
الماء،السـباحة،الغوص والانقاذ،البيسـبول والسـيفتبول، المبارزة ســلاح السـيف، كرةاليـد) وعملـة كشرف للانشطة الرياضية بالمنتجعات والفنادق السياحية ، راي انه كثثرمن المنتجعات والقري والمنشات الرياضية والاماكن الطبيعية والاثرية والاماكن السياحية غير مستغلة الاستغلال الامتل منل ( سباق الهجين - سفاري الصحراء سباقات الخيول -مسابقات الكانوى والكياك - مسابقات اسكواش وتنس - الجولف - البولنج- المشي - مسابقات الانقاذ ومسـابقات الغوص وسباحه الزعانف في النيل ومسـابقات الثنانتي والخماسي الحديث- التزلج علي الرمال - التزلج علي المياة - البالون - رالي التجديف) ومن خلال تلك البطولات المختلفة سوف نوجة انظار العالم الي صـعيد مصـر واحداث تتميـة ، كمـا ان هنـاك قصـور في الاهتمـام بتفعيل دور السياحة 
الرياضية علي مستوي محافظات جنوب الصعيد رغم وجود البيئه المناخية والجغرافية المناسبة لممارسـة منتل هـذه الانشـطة واقامـة العديـد مـن البطـولات التـي تشـاعد السـائحين في تلبيـة احتياجـاتهم، بالاضـافة الي قصـور في اعـلام بعض المسؤولين عن اقامـة الانشطة الرياضية المختلفة بتلك الامـاكن ، وايضـا عدم وجود خطـة للنهوض بالسياحة الرياضية من قبل هيئة تتشيط السياحة.

أيضـا خـلال المتابعـة و تحليـل الوثـائق أن مصـر تتمتـع بجغرافيـة سياحية، وظـروف مناخيـة، تجعلها صـالحة للسـياحة الرياضـية طـوال العـاموهن خـلاص ملاحظـة الباحـث إهمـال محافظات الصعيد على الرغم من أهميتها السياحية وامكانياتها وكذلك من خلاص قيام الباحث بالمسـح المرجعي، والاطـلاع على المراجـع، والدراسـات السـابقة، تبين لـه قلـة الدراسـات التي، تتاولت الامكانيات والموارد المتاحة بمحافظـات جنوب الصعيد على الرغم من ان محافظـات صعيد مصر تتميز بطبيعة سياحية خاصة حيث تحتوى على نسبة كبيره من معالم الحضارات

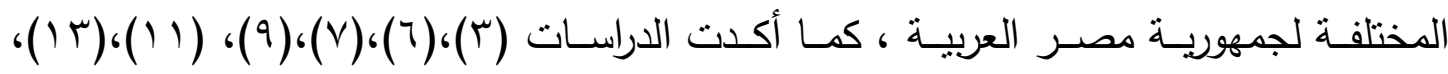

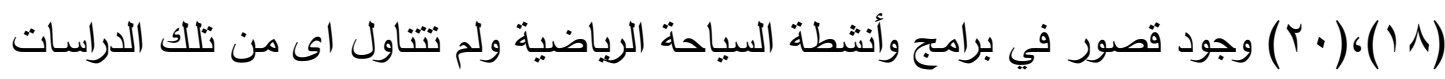
أو غيرها السياحة الرياضية في صعيد مصر بشكل مباشر ، وهذا ما دفع الباحث إلى محاولة التعرف على الموارد والامكانيات المتاحة للسياحة الرياضية بصعيد مصر ، ذلك للاستفادة من عمليـة ربطها بالرياضـة ومحاولـة وضـع دراسـة تحليليـةلالمكانيات والمـوارد المتاحة للسياحة الرياضية في محافظات جنوب الصعيد ذلك لوضعها على خريطة السياحة الرياضية بجمهورية مصر العربية ، مما قد يساهم في التتمية السياحية والاقتصادية لجمهورية مصر العربية. ويرى الباحث ضرورة الاستفادة من تلك الامكانات فى دعم الحركة السياحية الوافدة الى مصر فى وضع حجر الأساس لقيام الأنماط السياحية الأخرى غير السياحة الثقافية والتي تعتمد على قدوم السائحين الى مصر وجنوب الصعيد بغرض مشاهدة الآثار القديمة فالاستغلال الامثل ه ه 
للامكانات المادية والبشرية المتوفرة فى مجال السياحة الرياضية يمكن أن تجعل جنوب الصعيد بلداً سياحياً فى المقام الأول وتنتقطب ألوان من السـائحين بغرض السياحة الرياضية ـ فهذه الامكانـات تكفل أقامـة المباريـات والمسـابقات والمهرجانـات الرياضية فى كافـة أنواع الأنشطة الرياضية والبطولات الرياضية القارية العالميـة والإقليميـة فى مختلف الأنشطة الرياضية وتتفيذ ذللك بطريقة متميزة حتى نحقق التميز فى مجال التتافس السياحى لنحقق السبق عن المنافسين أهمية البحث والحاجة إليها : - الاستغلال المثل للموارد والامكانيات المتاحة - وسيلة لتبادل الثقافات واللغات - توفير فرص عمل للشباب - رفعة شان محافظات جنوب الصعيد بمصر والعالم هدف البحث : (1)

يهدف البحث الي دراسـة تحليلية لامكانيات والموارد المتاحـة للسياحة الرياضية بجنوب الصعيد وذلك من خلال التساؤلات - ما الواقع الفعلي لإمكانات السياحة الرياضية المادية والبشرية بجنوب الصعيد - ما هي الموارد والامكانيات للسياحة الرياضية بجنوب الصعيد؟ - ماهي انواع الانثطة والبطولات العالمية والاقليمية والمحلية التي تطبق علي محافظات جنوب الصعيد الاراسات السابقة والمرتبطة: 
- دراسة جمال محمد على،إبراهيم حسين، شيرين جال (r ( • rم) بعنوان:" تصسور مقترح لخريطة السياحة الرياضية بجمهوريـة مصر العربية"، تهدف الدراسـة إلى وضـع تصـور مقترح لخريطـة السياحة الرياضية بجمهوريـة مصـر العربيـة، مـن خـلال التعرف على واقع السياحة الرياضية بجمهوريـة مصر العربية،الرياضيات الخلويـة التي تتتاسب مـع المقومـات والطبيعـة وتسـاهم في تشكيل دوافع السياح لممارستها بجمهوريـة مصر العربية، استخدم الباحثون المنهج الوصفي "

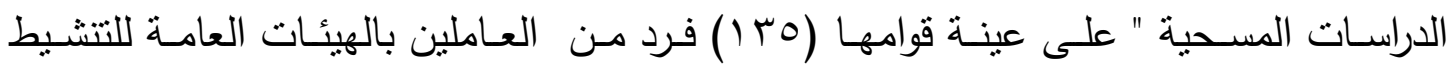
السياحي العاملين بوزارة السياحة، الأخصائيين الرياضيين بالقرى السياحية، المرشدين السياحيين،

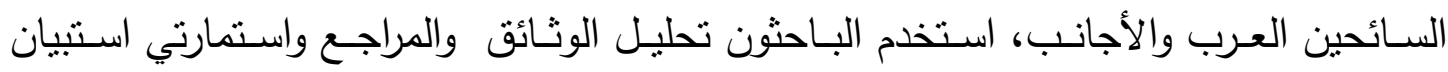
كأدوات لجمـع البيانـات، كانت أهم النتائج ضـرورة وضـع أهداف للسياحة الرياضية كمنظور اقتصادي يتتاسب مـع مقومات الدولة ككل وكل إقليم على حده، ضرورة وجود هيكل تتظيمي لإدارة السياحة الرياضية، سد أوجه القصور في برامج السباحة الرياضية، ضرورة التغلب على هلى معوقات السياحة الرياضية، تتظيم مهرجانات وأحداث رياضية تتجع على جذب السائحين من

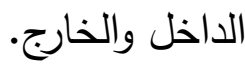
- دراسة "محمد أحمد خضرى" (10 • r م) هدفت إلى وضع نموذج مقترح لتفعيل مقومات السياحة الرياضية والعلاجية بمدينة سفاجا بمحافظة البحر الأحمر ،واستخدم الباحث المنهج الوصفى ،وبلغت عينة البحث 0 كفرد من القائمين على القرى السياحية بسفاجا، واستخدم الباحث فحص الوثائق والسجلات والإستبيان كأدوات لجمع البيانات ومن أهم النتائج هى وضع نموذج مقترح لتفغيل السياحة الرياضية والعلاجية ومعرفة المناشط الرياضية والعلاجية .

دراسة "أشرف الميداني" ( . . . rم) بعنوان "تقويم إمكانات السياحة الرياضية في جمهورية مصر العربيةة" وذلك من خلال التعرف على إمكانيات السياحة الرياضية في مصر ، والتعرف على مدى كفاية الإمكانيات المتوفرة بالفعل لنجاح السياحة الرياضية في مصر ، وما هو مطلوب 
من إمكانيات لنجاح السياحة الرياضية في مصر ، وما هي معوقات صناعة السياحة الرياضية في مصر، واستخدم الباحث المنهج الوصفي على عينة بلغن عددها ( • شخصية من القيادات العاملة في المجلس الأعلى للشباب والرياضة ومديري عام السياحة بالإسكندرية واستخدم الباحث

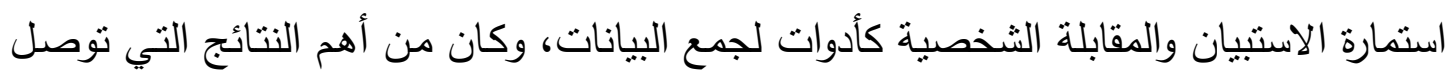
إليها أن إمكانيات السياحة الرباضية تعتبر احد أهم أساسيات النجاح لصناعة السياحة الرياضية

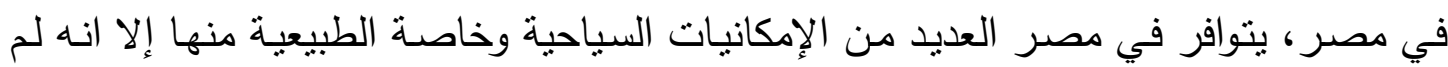
تستغل بالثكل المناسب، أن هناك قصور في الأنشطة الرياضية التي تقدمها القرى السياحية وعم وجود تتسيق بين الهيئات الرياضية والهيئات السياحية، كذلك عدم وجود خطط إعلامية كافية، عدم وجود أبطال عالميين، عدم توافر أخصائيين في مجال السياحة الرياضية بصوره كافية

دراسة "خالد محمدعزب" ( • rم) استهدفت التعرف على الإمكانات المتوافرة بالسياحة الترويحية الرياضية المادية والبشرية داخل المجتمعات السياحية مجتمع البحث ـ والتعرف على الأنشطة المفضلة لدى السائحين المترددين على المنتجعات السياحية بتلك المدينة مجتمع البحث • واسستخدم الباحث المنهج الوصفى ، واشتمل مجتمع البحث على السائحين المترددين على المنتجعات السياحية بمدينة رأس سدر ومديرى المنتجعات السياحية ـ ومن أهم النتائج التى توصل إليها الباحث أن كل منتجع سياحى مسئول عن التسويق الترويحى الرياضي السياحى بمفرده ولا دخل للجهات الأخرى منل شركات السياحة ، الإعلام ، وزارة السياحة .

دراسة "منى عبدالعزيز الحثاش" (^ . . rم) استهدفت تقويم إمكانات السياحة الرياضية في دولة الكويت ، وأستخدمت الباحثة المنهج الوصفى المسحى على عينة قوامها ( . . ه) فردا من خبراء الرياضـة والسياسـة والإقتصـاد والتجارة والأكاديميين والتربويين والقطاع الخاص والعام والسياحة

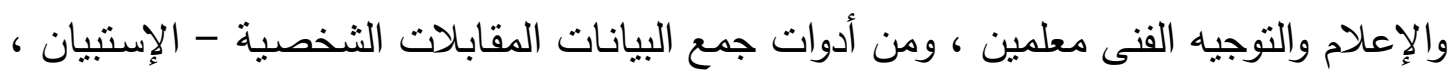
وتم إستخدام المعالجات الإحصائية معامل الإرتباط - النسبة المئوية - اختبار كاب - تحليل 
التباين • ومن أهم استخلاصـات البحث أن إمكانات السباحة الرياضية أهم أساسيات نجاح وترويج السياحة الرياضية في دولة الكويت ، على الرغم من توافر الإمكانات الطبيعية للسياحة

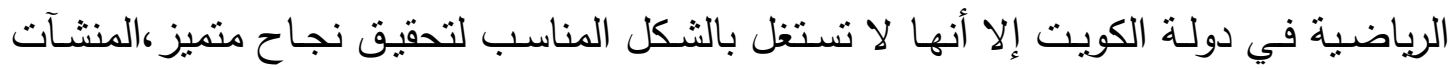
السياحية الرياضية لا تستغل بالقدر الكافي لنجاح السياحة الرياضية ، تعتبر الإمكانات المادية

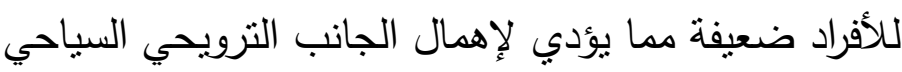

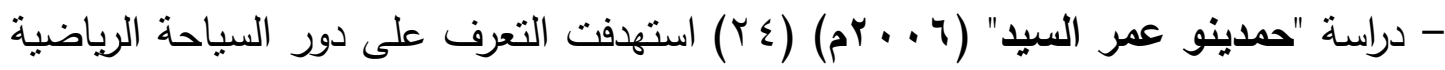
فى تتمية الجذب السياحى لجمهورية مصر العربية ،والتعرف على أهم الرياضات الجاذبة للسائحين ،مستخمدما المنهج الوصفى ،وبلغت عينة البحث ( . . . ( )سائح من جنسيات مختلفة ،واستخدم الباحث الإستبيان كأداة لجمع البيانات ، ومن أهم النتائج أن أعلى إسهامات السياحة الرياضية فى إثباع الدوافع الرئيسية للسفر لدى السائحين هى التمتع بالممارسة فى الطبيعية

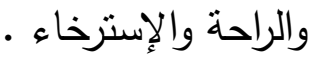

- دراسة :أحمد نبيل الثيخ" (ع + . rم) (• () استهدفت التعرف على دور السياحة الرياضية فى تتمية الموارد بالإتحادات الرياضية من وجهة نظر المسئولين عن السياحة الرياضية من الإتحادات والإعلام والسياحة والتربية الرياضية ومن وجهة نظر السياح الأجانب المتحدثين باللغة العربية والإنجليزية ـ واستخدم الباحث المنهج الوصفى "الدراسات المسحية " على عينة بلغ

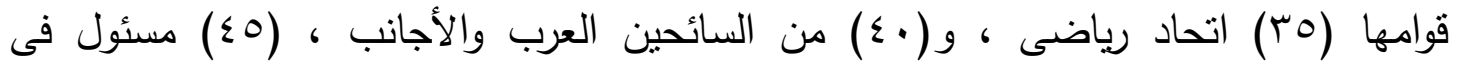
السياحة والإعلام والتربية الرياضية ـ واستخدم الباحث استمارة الإسنبيان والمقابلة الثخصية كأدوات لجمع البيانات .وكان من أهم النتائج التى توصل الباحث أنه على الرغم من نوافر الإمكانيات الطبيعية والمناخية والتاريخية والدينية ألا أنها لا تستغل بالثكل المناسب لتحقيق نجاح متميز ، لا يتوافر فى مصر الأخصائيون القادرون على العمل فى مجال السياحة والفنادق 
والتخصصات التى تؤهلهم لذلك ، المنشأت السياحية والرياضية لا تصلح لنجاح السياحة الرياضية والصالح منها لا يستغل بالقدر الكافى

\section{الاسراسات الاجنبية:}

- دراسة ريشارد كوليمان Richard Coleman ( • ( + ) استهدفت تحديد العوائد الإقتصادية من استضافة الأحداث والمسابقات الرياضية ، واستخدم الباحث المنهج الوصفى ، وبلغت عينة البحث (ro)مسئول من المسئولين عن المسابقات الرياضية واستضافتها بالولايات المتحدة الأمريكية ، ومن أهم نتائج البحث أنه نتيجة استضافة المسابقات والدورات الرياضية بالمدن الأمريكية يحدث اهتمام بالتتمية الإقتصادية للمدن وتتمية منشئاتها العامة والحيوية .

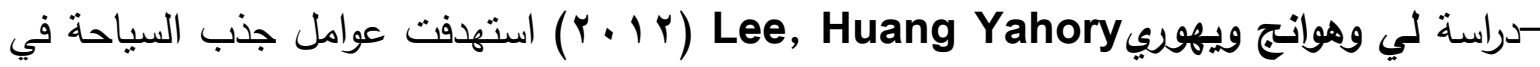
تايوان التعرف على عوامل جذب السياحة في تايوان وستخدم المنهج الوصفي وبلغت العينة

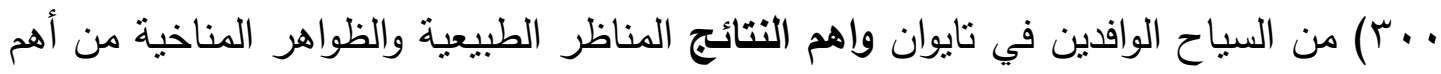
السمات التي تحدد جاذبية السياحة الترويحية بالاضافة إلى توفير الخدمات الترفيهية والتجهيزات السباحية

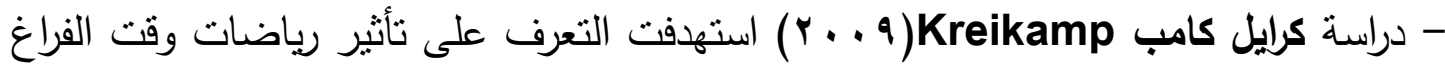
على تطور السياحة وذلك من خلال التعرف على البيانات الحالية لرياضة الجولف .واستخدم الباحث المنهج الوصفى على عينة من الممارسين لرياضة الجولف فى كل من ألمانيا وأسبانيا وإيطاليا والبرتغال وأيرلندا واستراليا وكندا والولايات المتحدة الأمريكية ، واستخم الباحث الباحث إستمارة الإستبيان كاداة لجمع البيانات وكان من أهم النتائج التى توصل إليها الباحث : أن متوسط نصيب الفرد من ملاعب الجولف التى بها (1/) حفرة فى ألمانيا يبلغ ... (فرد 


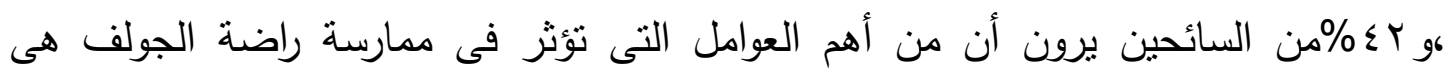
الطقس ثم نوافر اماكن الممارسة بشكل جيد.

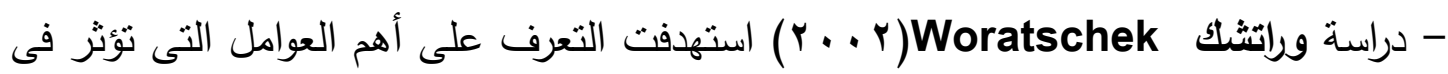
جودة الخدمات السياحية والتى يكون لها إنعكاسات على معدلات الرضا لدى السائحين •واستخدم الباحث المنهج الوصفى على مجموعة من السائحين المترددين على المشروعات السياحية وتم إختيارهم بطريقة عشوائية ، واستخدم الباحث الإستبيان والمقابلة الشخصية كأدوات لجمع البيانات •وكان من أهم النتائج التى توصل اليها الباحث : أن السكان فى المناطق السياحية تأتى فى مقدمة العوامل التى تؤثر فى مسنتى جودة الخدمات السياحية بمتوسط حسابى مقداره (T.VT) فى حين كانت عروض الخدمات الرياضية هى احد اهم تلأك العوامل بمتوسط (ץ^) متقدمة بذلك على الثير من العوامل الاخرى مثل خدمات وقت الفراغ وخدمات التاكسى ووسائل المواصلات.

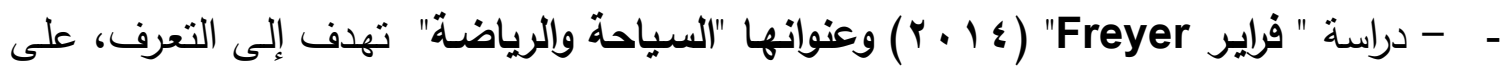
أهم الرياضات التي تناهم في الترويج السياحي لاي السائحين الألمان، واستخدم الباحث المنهج الوصفي على مجموعة من السـائحين الألمان، تم اختيارهم بطريقة عشوائية، واستخدم الباحث استمارة الاستبيان والمقابلة الثخصية، كأدوات لجمع البيانات، وكان من أهم النتائج التي توصل التهل

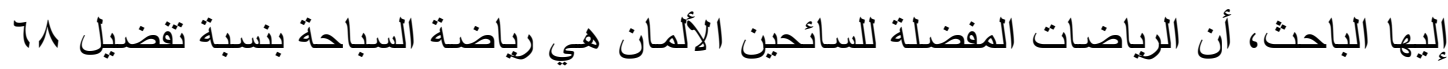

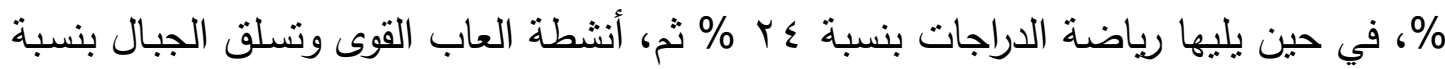
r Y \% ثم رياضة كرة القدم بنسبة 10 \% \%، في حين تأتي في نهاية تلك الرياضات المفضلة، كلا من التسس، والكرة الطائرة، بنسبة مئوية قدرها 9 (1\%.

إجراءات البحث : منهج البحث: 
استخدم الباحث المنهج الوصفي (الدراسات المسحية) وذلك لمناسبته وطبيعة البحث.

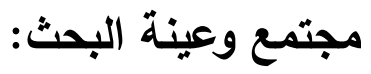

يمثل مجتمع البحث العاملين في مجال السياحة والسياحة الرياضية والترويح الرياضي، الإدارة الرياضية قام الباحث باختيار عينـة البحث باسلوب الحصر الثـامل بجنوب الصعيد الاقصر واسوان ذلك كما قسمتها وزارة السياحة وقد تم اختيار عينة البحث بالطريقة العشوائية حيث بلغ

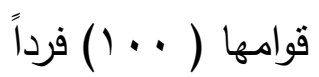

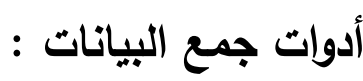

قام الباحث بتصميم استمارة استبيان كاداه لجمع البيانات وقد استهدف هذا الاستبيان التعرف على الامكانات والموارد المتاحة للسياحة الرياضية بجنوب الصعيد 
وفقاً للخطوات التالية: ت

$$
\text { - تحديد المحاور والعبارات: }
$$

- - مـن خـلال الإطـلاع على الدراسـات السـابقة والمرتبطـة بمتغيـرات البحث والمراجـع العلميـة تم التوصل الي الموارد المرتبطة بالسياحة الرياضية.

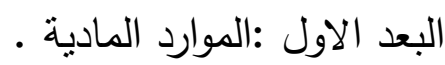
البعد الثاني :الموارد البشرية. البعد الثالث :الموارد الطبيعية.

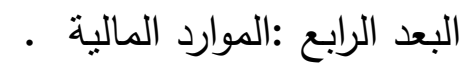
البعد الخامس الموارد المعلوماتية.

\section{المعاملاث العلمية لاستمارة الاستبيان:}

قام الباحث بحساب صدق استمارة الاستبيان من خلال (صدق المحتوي)

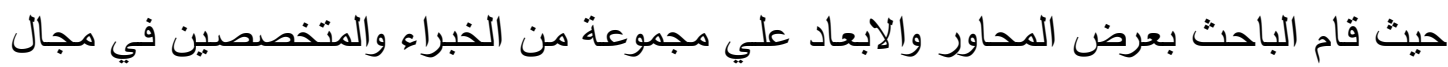
الادارة الرياضية والترويح الرياضي والسياحة التي تتوفر فيهم الثروط عددهم ( • () خبيرا مرفق

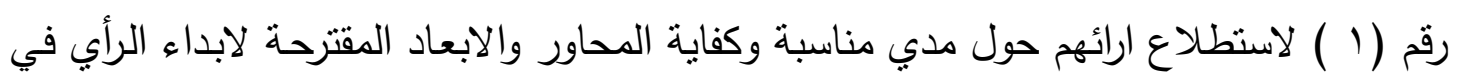
مدي ملائمتها لتحقيق اهداف البحث. 


\section{جدول (1)}

نتائج استطلاع أراء الخبراء حول محاور استمارة الاستبيان للتعرف على اهداف السياحة الرياضية، واللارجة الترجيحية لكل محور وكذلك الترتيب

المحور الأول :الموارد المرتبطة بالسياحة الرياضية

\begin{tabular}{|c|c|c|c|c|c|}
\hline \multicolumn{6}{|c|}{ البعد الاول: الموارد المادية :- } \\
\hline$\% 0, Y\urcorner$ & 1 & $\% q \leq, V T$ & 11 & 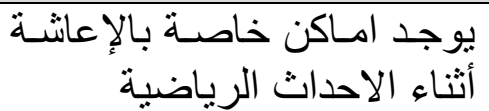 & 1 \\
\hline$\% 1 \cdot, 0 Y$ & $Y$ & $\% \wedge 9, \leqslant \vee$ & IV & 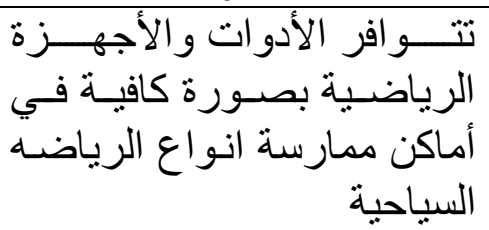 & r \\
\hline$\% 1 \cdot$, Or & r & $\% \wedge 9, \leqslant \vee$ & IV & 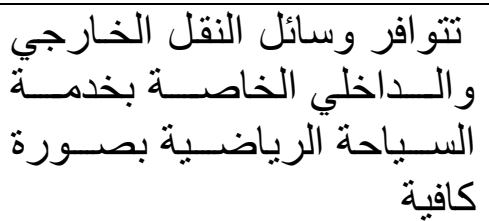 & $r$ \\
\hline$\% 0, Y \uparrow$ & 1 & $\% q \varepsilon, V T$ & 11 & 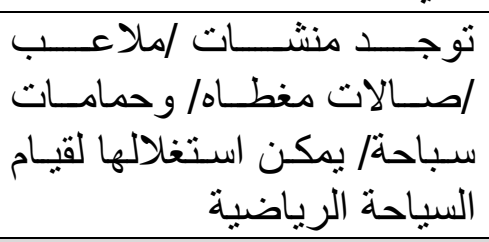 & $\varepsilon$ \\
\hline \multicolumn{6}{|c|}{ البعد الثاني :الموارد البشرية :- } \\
\hline$\% 1 \cdot, 0 Y$ & r & $\% \wedge q, \leqslant \vee$ & IV & 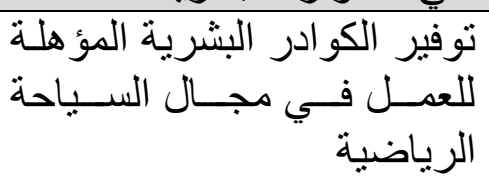 & 0 \\
\hline$\% 10, \vee \wedge$ & r & $\% \wedge \varepsilon, Y)$ & 17 & 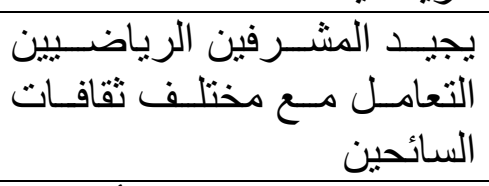 & 7 \\
\hline$\% 1 \cdot, 0 r$ & r & $\% \wedge 9, \leqslant \vee$ & iv & 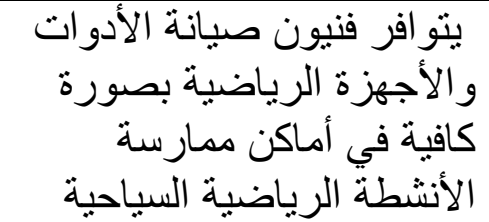 & V \\
\hline
\end{tabular}




\begin{tabular}{|c|c|c|c|c|c|}
\hline$\% 0, r u$ & 1 & $\% q \leq, \vee r$ & 11 & 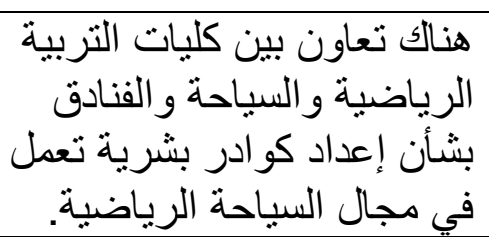 & $\wedge$ \\
\hline$\% 0, r u$ & 1 & $\% q \leq, \vee r$ & 11 & تلتهاهم فيئات تدريب كو استثارية خاصر بشرية & 9 \\
\hline$\% 1 \cdot, 0 r$ & r & $\% \wedge q, \leq \vee$ & iv & 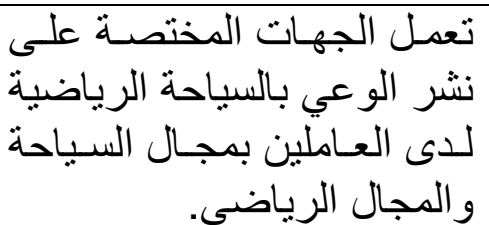 & 1. \\
\hline$\% 1 \cdot$, or & r & $\% \wedge 9, \leqslant \vee$ & iv & 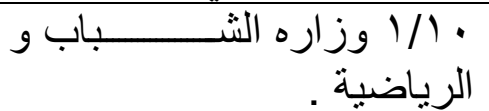 & \\
\hline$\% 1 \cdot, 0$ r & $r$ & $\% \wedge 9, \leqslant \vee$ & IV & • ب/I وزاره السياحة & \\
\hline$\% 1 \cdot$, or & r & $\% \wedge 9, \leqslant \vee$ & iv & و الرياضة / آمديريـــــــة الثـــــــاب & \\
\hline & & & & الثالث :الموارد الطبيعية :- & 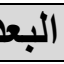 \\
\hline$\% 0, r q$ & 1 & $\% q \varepsilon, V \Gamma$ & 11 & 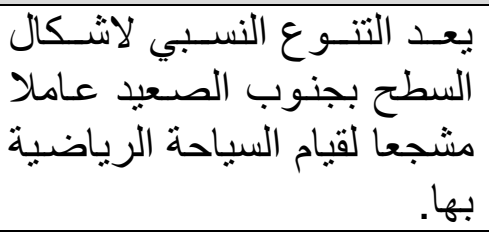 & 11 \\
\hline$\% 1 \cdot, o r$ & r & $\% \wedge q, \varepsilon \vee$ & iv & تعتبر البيئة الصحر القيام السية مجالا الرياضة & ir \\
\hline$\% 10, \mathrm{~V}$ & r & $\% \wedge \varepsilon, Y)$ & 17 & 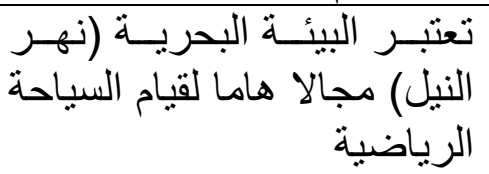 & r \\
\hline$\% 1 \cdot, o r$ & r & $\% \wedge q, \varepsilon \vee$ & iv & 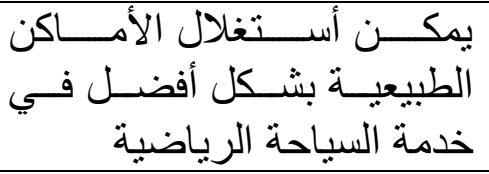 & $1 \varepsilon$ \\
\hline$\% 0, Y_{7}$ & 1 & $\% q \varepsilon, V Y$ & 11 & تعنبر القو امل المناخية عو امل السياحة الرياضية & 10 \\
\hline \multicolumn{6}{|c|}{ البعد الرابع :الموارد المالية :- } \\
\hline
\end{tabular}




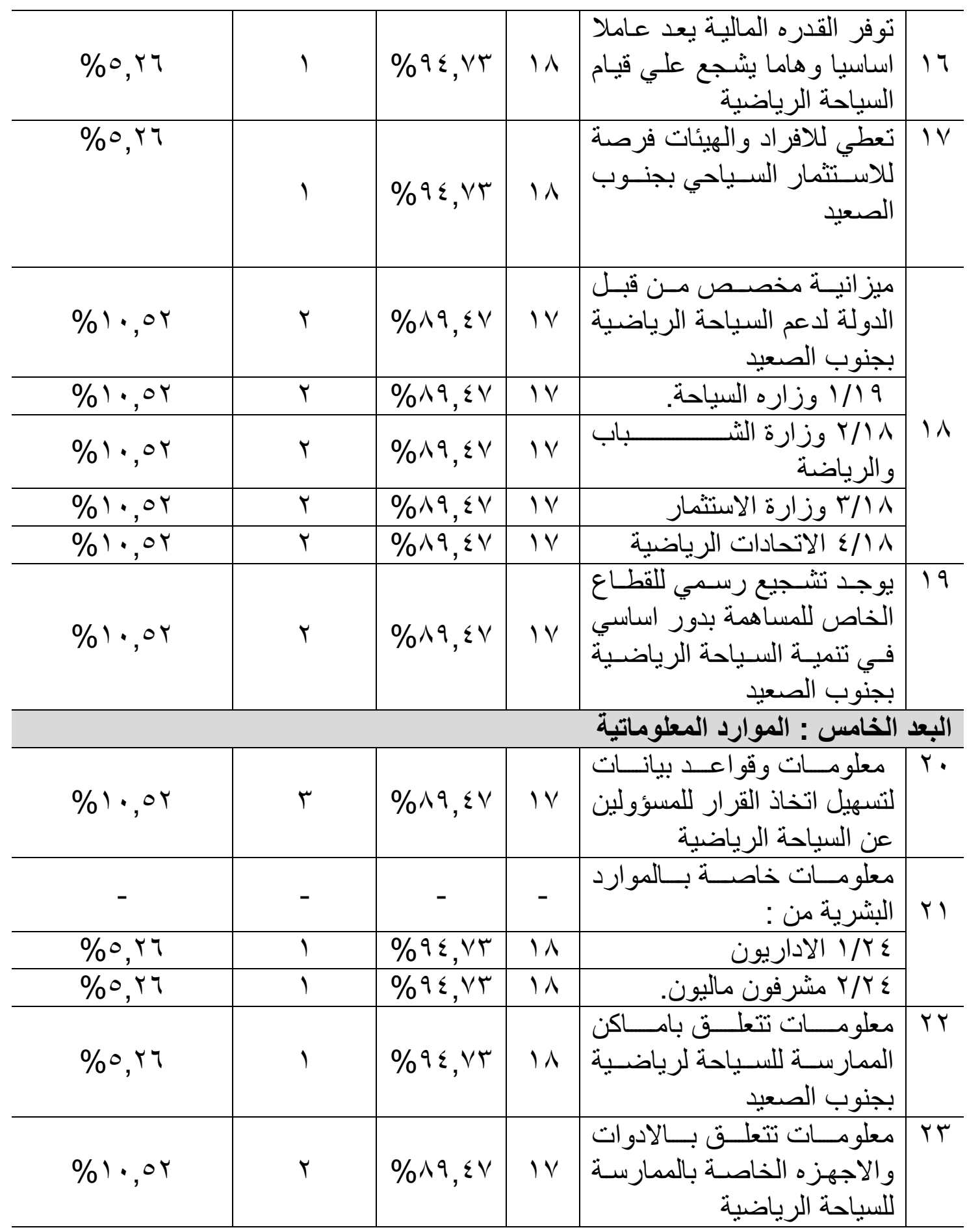




\begin{tabular}{|c|c|c|c|c|c|}
\hline$\% 1 \cdot, 0 r$ & r & $\% \wedge q, \leq \vee$ & iv & 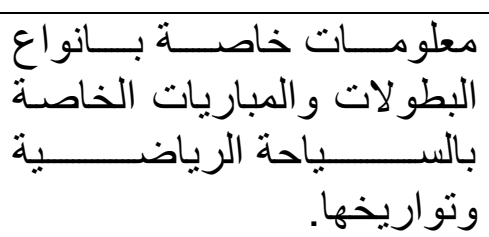 & $r \varepsilon$ \\
\hline$\% \backslash 0, \vee \wedge$ & 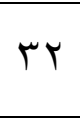 & $\% \wedge \varepsilon, r)$ & 17 & 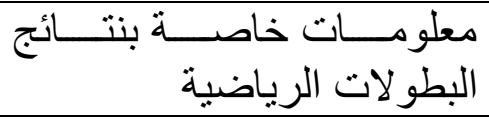 & ro \\
\hline$\% \backslash 0, \vee \wedge$ & r & $\% \wedge \varepsilon, r)$ & 17 & 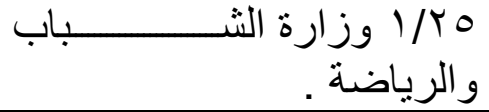 & \\
\hline$\% 10, \vee \wedge$ & $r$ & $\% \wedge \varepsilon, Y_{1}$ & 17 & ه/r/r وزاره السياحة . & \\
\hline$\% 10, \vee \wedge$ & $r$ & $\% \wedge \varepsilon, Y_{1}$ & 17 & 0/T/ الاتحادات الرياضية . & \\
\hline$\% \backslash 0, \vee \wedge$ & r & $\% \wedge \varepsilon, Y)$ & 17 & لالعاب المختلفة ـ المنــاطق الرياضـــية & \\
\hline$\% \backslash 0, \vee \wedge$ & r & $\% \wedge \leq, Y)$ & 17 & 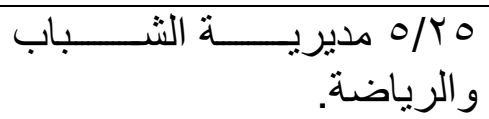 & \\
\hline
\end{tabular}

الموارد المرتبطة بالسياحة الرياضية

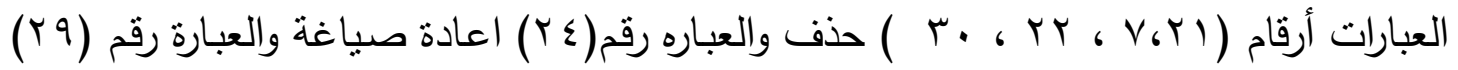
دمج من محور الموارد المرتبطه صدق الاتساق الداخلي

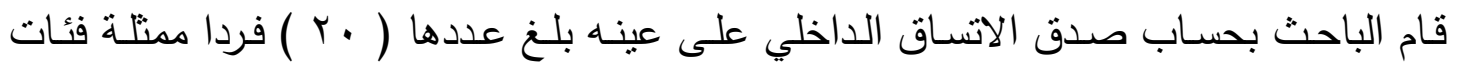
مجتمع البحث ومن خارج العينة الاساسية وذلك لحساب معامل الارتباط بين درجوة كل عبارة وبين درجة المحورالتي تتنمي الية وحساب معامل الارتباط بين درجة كل محور والدرجة الكلية لاستمارة الاستبيان

\begin{tabular}{|c|c|c|}
\hline$* * . .7 r$. & 1 & \multirow{4}{*}{ الاول } \\
\hline$* * \ldots Y r$ & r & \\
\hline$* * . .79 \mathrm{~V}$ & r & \\
\hline$* *$ *. . $0 \leqslant$ & $\varepsilon$ & \\
\hline$* * . .01$ & 0 & \\
\hline **, . V & 7 & \\
\hline
\end{tabular}




\begin{tabular}{|c|c|c|}
\hline$* *, . \vee \leqslant 0$ & V & \multirow{6}{*}{ الثانى } \\
\hline$* * .79 \mathrm{~V}$ & $\Lambda$ & \\
\hline$* * . \wedge 0 \leqslant$ & 9 & \\
\hline$* * . .0 \mathrm{~V} 7$ & $1 / 1$. & \\
\hline$* * . \vee T \wedge$ & $r / 1$. & \\
\hline **. . OY & $r / l$. & \\
\hline$* * \cdot .7 \cdot \Lambda$ & 11 & \multirow{5}{*}{ الثالث } \\
\hline **. . Tr. & Ir & \\
\hline **..V\\
& H & \\
\hline$* * .79 V$ & $1 \varepsilon$ & \\
\hline$* *$ *. $\wedge 0 \leq$ & 10 & \\
\hline$* * . .0, r$ & 17 & \multirow{7}{*}{ الرابع } \\
\hline ** . .VRᄉ & IV & \\
\hline$* * . \wedge 0 \leq$ & $1 / 11$ & \\
\hline * . . $\leqslant T r$ & $r / / \Lambda$ & \\
\hline **..VT人 & $\Gamma / \Lambda$ & \\
\hline$* *$. . $7 \vee 9$ & $\varepsilon / 11$ & \\
\hline **. . OrV & 19 & \\
\hline$* * .79 V$ & $r$. & \multirow{3}{*}{ لخامس } \\
\hline$* *$ *. $\wedge \circ \leqslant$ & $1 / Y_{1}$ & \\
\hline **..フ & $r / Y I$ & \\
\hline
\end{tabular}

يتضـح من الجدول أن معاماتل صدق الاتسـاق الداخلي بين درجة كل عبارة واجمالى درجـة المحور

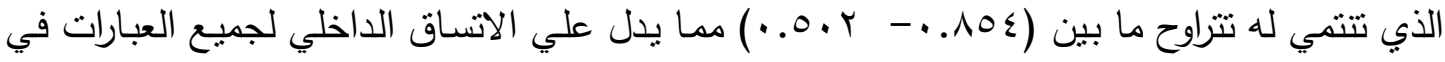
الاستبيان حيث ان الادلة معامل الاتسـاق عند هذه دالة إحصـائيا عند مستوى معنوبـة ( ه. . ) $\cdot(\cdot, r), Y)$ 
الموارد المرتبطة بالسياحة الرياضية

التكرارات والنسب المئوية وترتيب عبارات المحور الثاني في ضوء المتوسط المرجح و كاب لاستجابات العينة قيد البحث

\begin{tabular}{|c|c|c|c|c|c|c|c|c|c|c|c|c|c|}
\hline \multirow{2}{*}{ قيمة كا׳ } & \multirow{2}{*}{ لترتيب } & \multirow{2}{*}{ الاهمية } & \multirow{2}{*}{ |ترجيحى } & \multicolumn{2}{|c|}{ غير موافق } & \multicolumn{2}{|c|}{ الى حدا ما } & \multicolumn{2}{|c|}{ موافق } & \multirow{2}{*}{$\varepsilon$} & \multirow{2}{*}{ b } & \multirow{2}{*}{ 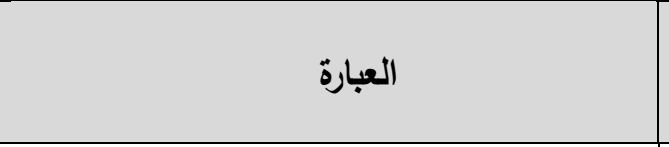 } & \multirow{2}{*}{ 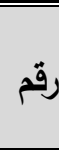 } \\
\hline & & & & $\%$ & 5 & $\%$ & 5 & $\%$ & 5 & & & & \\
\hline $89.17 *$ & 6 & 84.66 & 508 & 8.5 & 17 & 29 & 58 & 62.5 & 125 & 0.648 & 2.54 & هجد اماكن خاصة بالإعاثشة أثناء الاحداث الرياضية & 1 \\
\hline 95.77* & 19 & 73.83 & 443 & 7.5 & 15 & 63.5 & 127 & 29 & 58 & 0.566 & 2.22 & |فر الأدوات والأجزة الرياضية بصورة كافية في أماكن & 2 \\
\hline 29.83* & 26 & 71.5 & 429 & 18 & 36 & 49.5 & 99 & 32.5 & 65 & 0.697 & 2.15 & |نوافر وسائل النقل الخارجي والداخلي الخاصة بخدمة & 3 \\
\hline $49.63^{*}$ & 11 & 79.66 & 478 & 10.5 & 21 & 40 & 80 & 49.5 & 99 & 0.671 & 2.39 & |- مـنشات /ملاعب /صنالات مغطاه/ وحمامات سباحة/ & 4 \\
\hline $82.12^{*}$ & 8 & 84 & 504 & 9 & 18 & 30 & 60 & 61 & 122 & 0.657 & 2.52 & |فير الكوادر البشرية المؤهلة للعمل في مجال السياحة & 5 \\
\hline $86.77^{*}$ & 7 & 84.5 & 507 & 5 & 10 & 36.5 & 73 & 58.5 & 117 & 0.592 & 2.54 & جيد المشرفين الرياضيين التعامل مع مختلف ثقافات & 6 \\
\hline 69.73* & 27 & 70.16 & 421 & 14.5 & 29 & 60.5 & 121 & 25 & 50 & 0.621 & 2.11 & كافية في أماكن ممارسة الأنشطة الرياضية السيانة الأدياحية الرياضية بصورة & 7 \\
\hline $69.76^{*}$ & 9 & 82.66 & 496 & 8 & 16 & 36 & 72 & 56 & 112 & 0.642 & 2.48 & |هناكت تعاون بين كليات التربية الرياضية والنياحة & 8 \\
\hline
\end{tabular}




\begin{tabular}{|c|c|c|c|c|c|c|c|c|c|c|c|c|c|}
\hline & & & & & & & & & & & & السياحة الرياضية. & \\
\hline $56.11 *$ & 10 & 81 & 486 & 10.5 & 21 & 36 & 72 & 53.5 & 107 & 0.676 & 2.43 & |لـ هية للعملت استثمارية خاصة تسـاهم في تدريب كوادر & 9 \\
\hline $35.08 *$ & 17 & 76 & 456 & 25 & 50 & 22 & 44 & 53 & 106 & 0.839 & 2.28 & |لل الجهـات المختصـة على نشـر الـوعي بالسـياحة & 10 \\
\hline
\end{tabular}

التكرارات والنسب المئوية وترتيب عبارات المحور الثاني في ضوء المتوسط المرجح و كاץ لاستجابات العينة قيد البحث

\begin{tabular}{|c|c|c|c|c|c|c|c|c|c|c|c|c|c|}
\hline \multirow{2}{*}{ قيمة كا؟ } & \multirow{2}{*}{ الترتيب } & \multirow{2}{*}{ | الاهمية } & \multirow{2}{*}{ |تربيطى } & \multicolumn{2}{|c|}{ غير موافق } & \multicolumn{2}{|c|}{ الى حدا ما } & \multicolumn{2}{|c|}{ موافق } & \multirow{2}{*}{$\varepsilon$} & \multirow[b]{2}{*}{ r } & \multirow{2}{*}{ العبارة } & \multirow{2}{*}{ رقم } \\
\hline & & & & $\%$ & s & $\%$ & s & $\%$ & ك & & & & \\
\hline $27.01 *$ & 25 & 71.5 & 429 & 18.5 & 37 & 48.5 & 97 & 33 & 66 & 0.705 & 2.15 & لهـ السياحة & 10 \\
\hline 22.87 & 30 & 63.83 & 383 & 30 & 60 & 48.5 & 97 & 21.5 & 43 & 0.714 & 1.92 & يـة الثباب والرياضة & 10 \\
\hline $45.64 *$ & 12 & 79.66 & 478 & 14 & 28 & 33 & 66 & 53 & 106 & 0.721 & 2.39 & 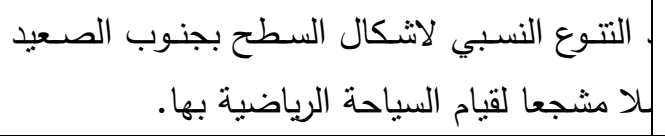 & \\
\hline $52.02 *$ & 1 & 91.83 & 551 & 0 & 0 & 24.5 & 49 & 75.5 & 151 & 0.431 & 2.75 & 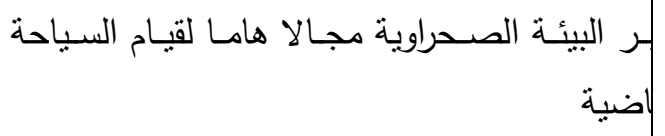 & \\
\hline $21.61^{*}$ & 28 & 64.83 & 389 & 28.5 & 57 & 48.5 & 97 & 23 & 46 & 0.717 & 1.95 & لـاحة البيائة البحريـة (نهـر النيـل) مجـالا هامـا لقيـام & \\
\hline 99.31* & 2 & 85.83 & 515 & 4 & 8 & 34.5 & 69 & 61.5 & 123 & 0.571 & 2.58 & لـن أستغغلال الأمـاكن الطبيعيـة بشكل أفضـل في & \\
\hline
\end{tabular}




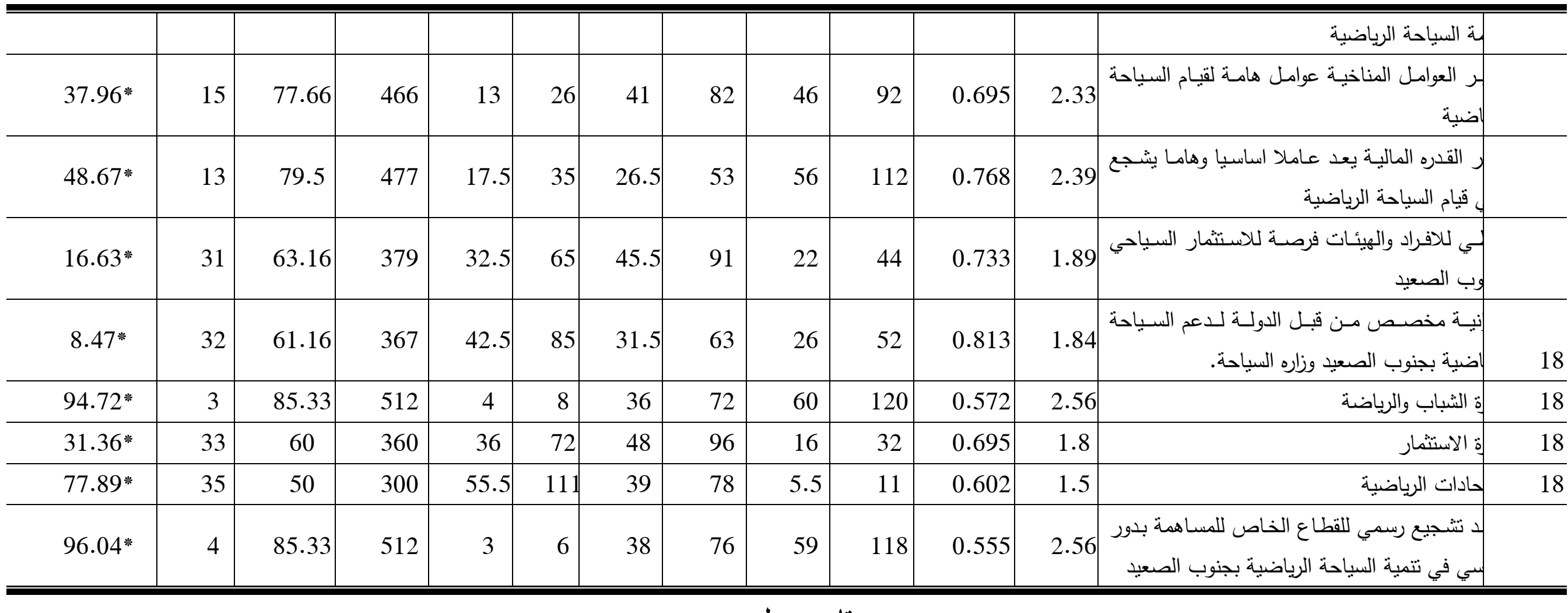

\section{تابع جدول}

التكرارات والنسب المئوية وترتيب عبارات المحور الثاني في ضوء المتوسط المرجح و كاب لاستجابات العينة قيد البحث

\begin{tabular}{|c|c|c|c|c|c|c|c|c|c|c|c|c|c|}
\hline \multirow{2}{*}{ قيمة كا؟ } & \multirow{2}{*}{ لترتيب } & \multirow{2}{*}{ الاهمبية } & \multirow{2}{*}{ تترجيحى } & \multicolumn{2}{|c|}{ غير موافق } & \multicolumn{2}{|c|}{ الى حدا ما } & \multicolumn{2}{|c|}{ موافق } & \multirow{2}{*}{$\varepsilon$} & \multirow{2}{*}{$b$} & \multirow{2}{*}{ العبارة } & \multirow{2}{*}{ رقم } \\
\hline & & & & $\%$ & s & $\%$ & s & $\%$ & ك & & & & \\
\hline $18.91 \%$ & 23 & 72.33 & 434 & 19.5 & 39 & 44 & 88 & 36.5 & 73 & 0.731 & 2.17 & 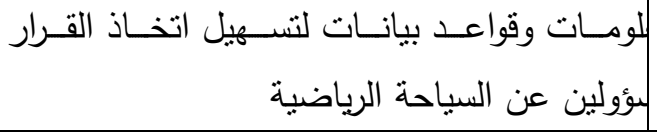 & \\
\hline
\end{tabular}




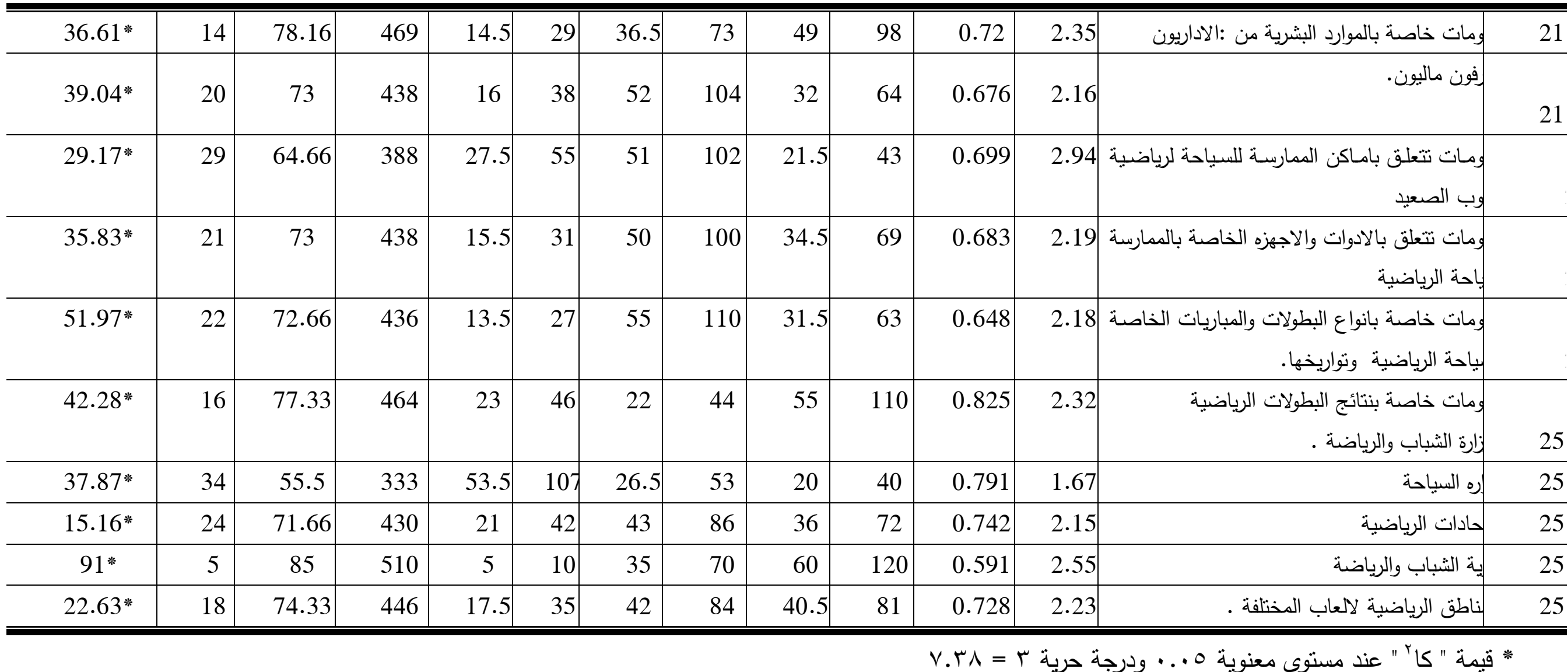




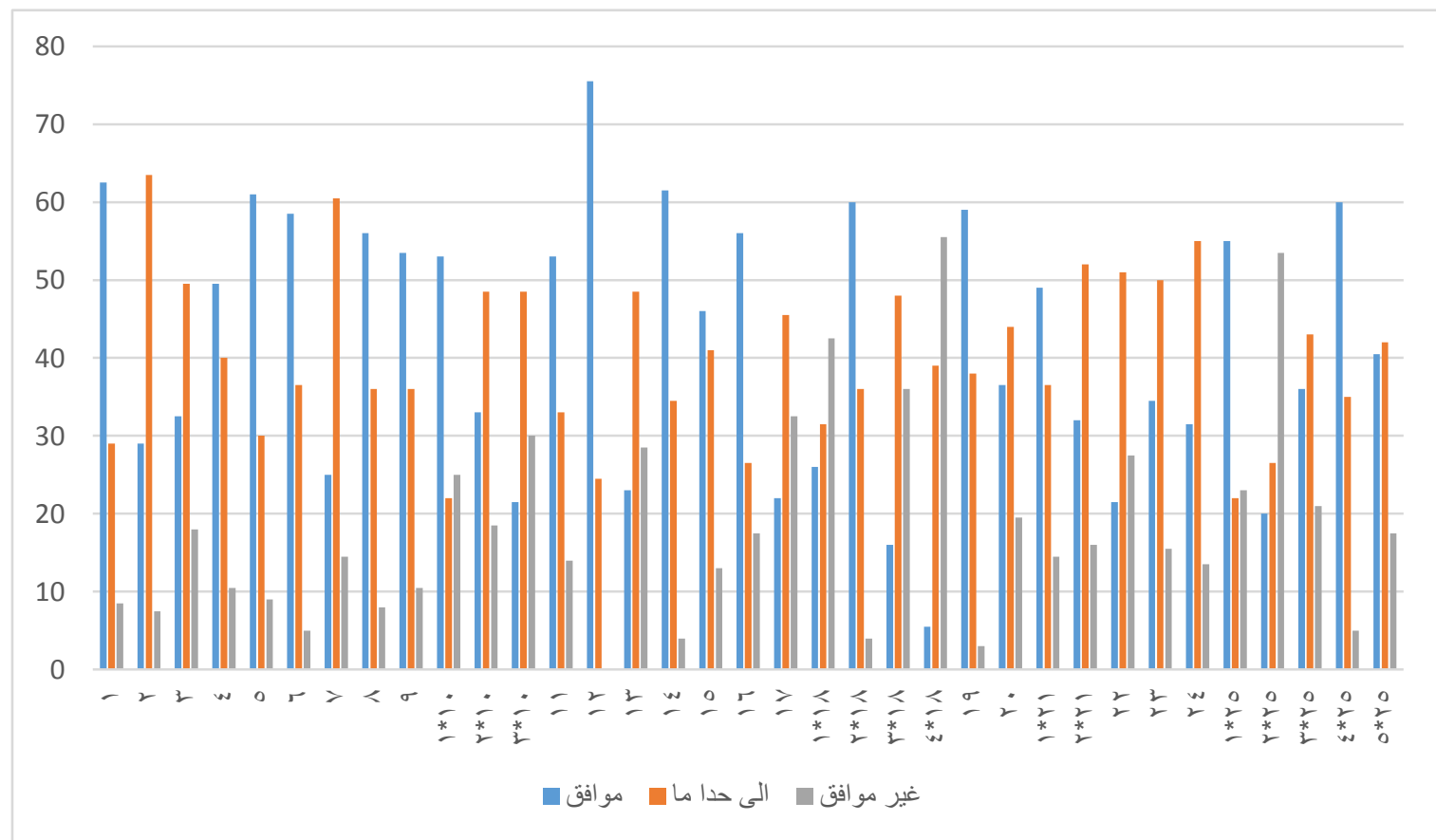

شكل ( §/ ) التكرارات والنسب المئوية وترتيب عبارات الدحور الثاني في ضوء المتوسط المرجح و كاب لاستجابات العينة

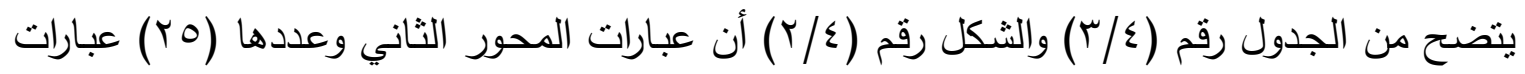
والخاصـه بـالموارد المرتبطة بالسياحة الرياضية جاءت كلها دالة إحصـائياً، حيث تعدت قيمـة كا؟

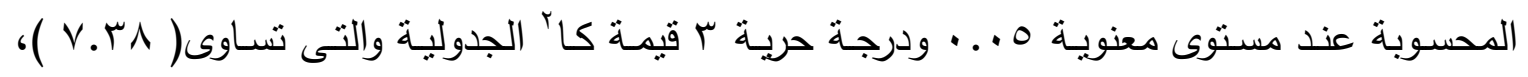

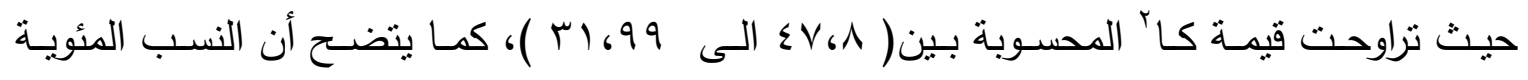

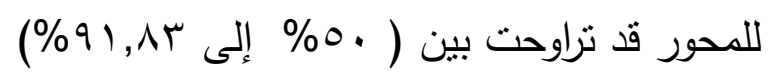

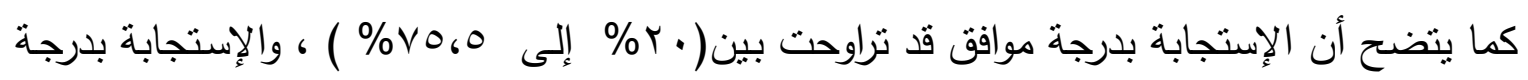
الى حدا ما قد تراوحت بين( r r \% إلى ه،r\%\%) ، والإستجابة بدرجة غير موافق قد تراوحت ما

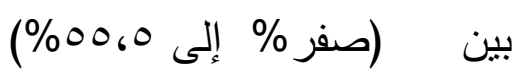

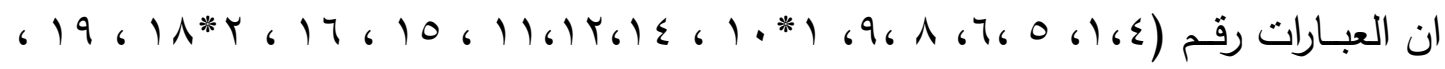

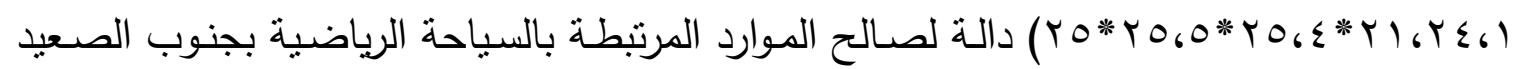

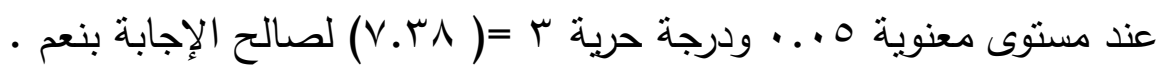

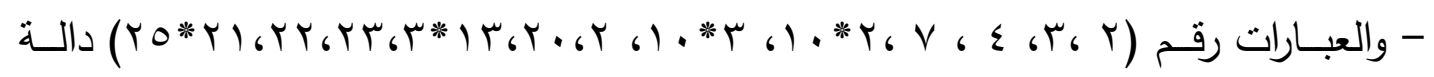
لصالح الموارد المرتبطة بالسياحة الرياضية بجنوب الصعيد عند مستوى معنوية ه . . . ودرجة حرية r = ^ץ.V ل لصالح الإجابة ب( الى حد ما ) . 


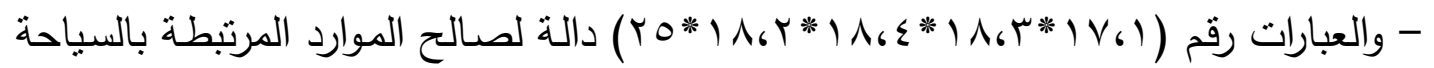

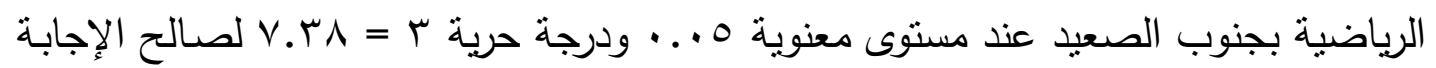

الموارد المرتبطه بالسياحه الرياضيه

يتضح من نتائج المحور الثاني الموارد المرتبطه بالسياحه الرياضيه جاء في التربه التربيب الاول العباره

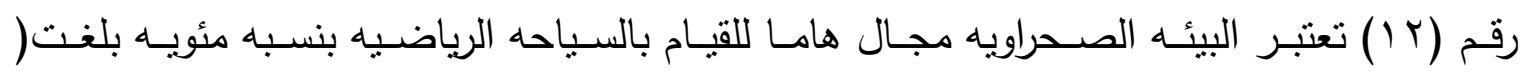

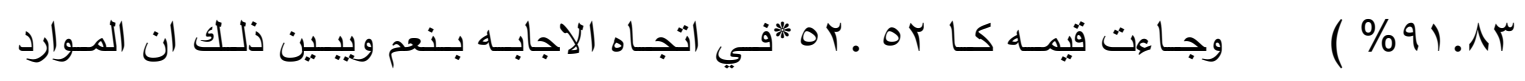
والامكانيات الطبيعيه المرتبطه بالسياحه الرياضيه ان البيئه الصحراويه الموجوده بجنوب الصاه الصعيد

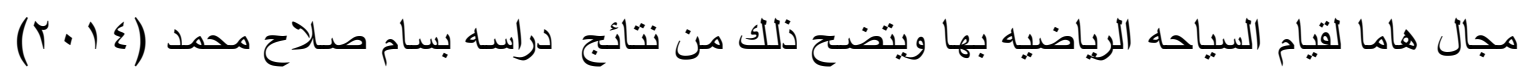

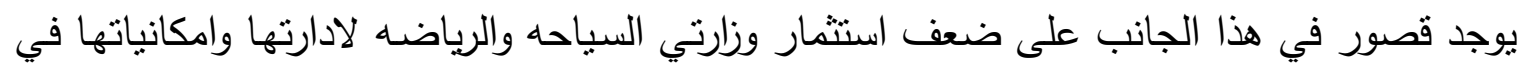

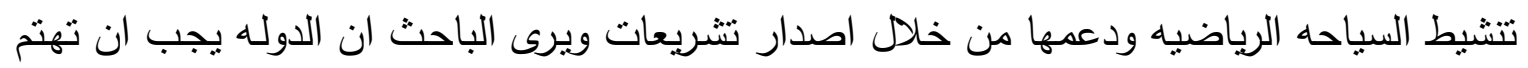

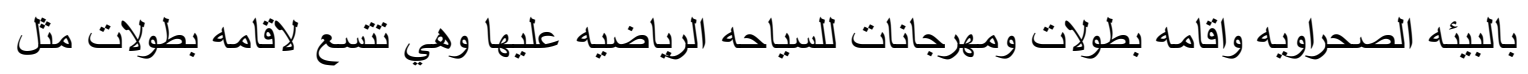

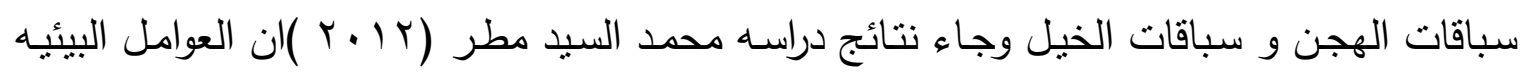

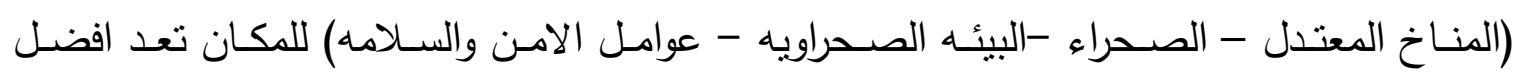

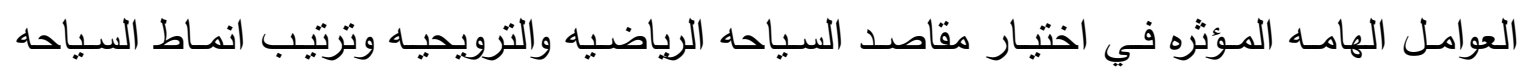

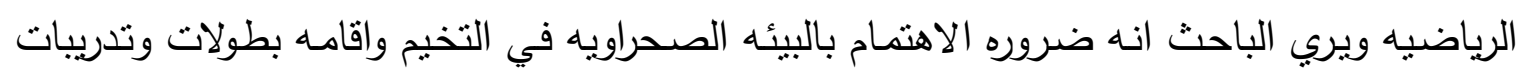

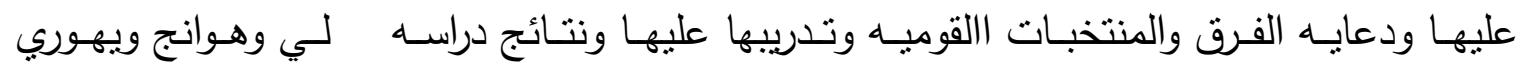
Lee,Huang, .Yahory جاذبيه السياحه الرياضيه بالاضافه الى توفير الخدمات التزفيهيه والتجهيزات للسياحه

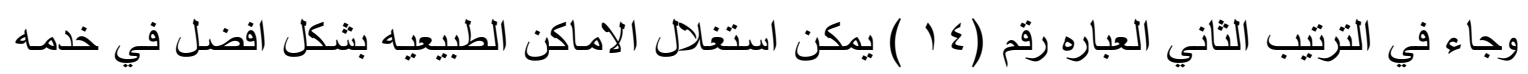

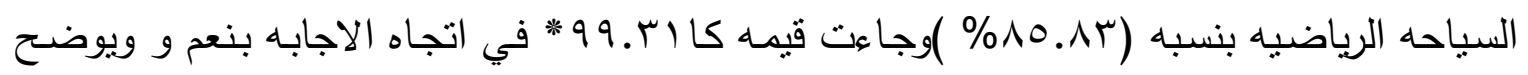
ذلك انه يجب الاهتمام واستغلال الاماكن الطبيعيه والاثرية بشكل افضل في طريق السياحه الرياضيه والامكانيات البيئه الطبيعيه من مناطق اثريه وشواطئ ونهر النيل ، متميزه للاستفاده منها بالثنكل

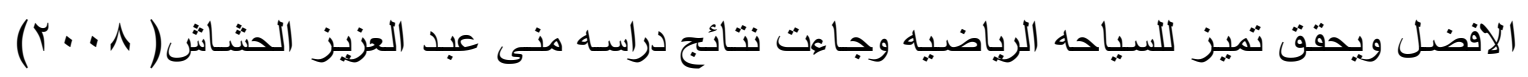

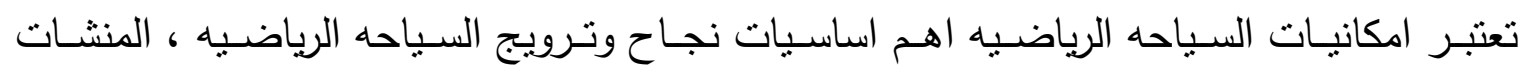

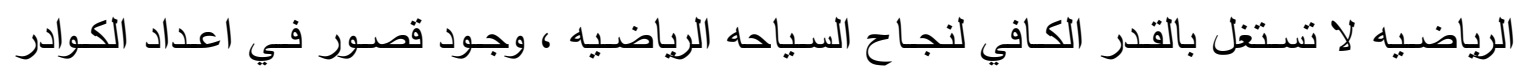

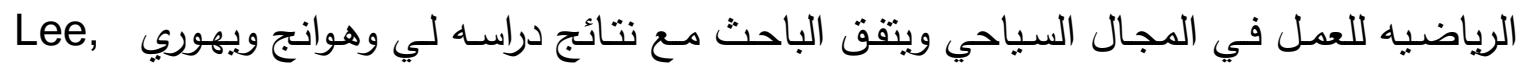
Huan,Yahory الجاذبيه للسياحه الرياضيه بالاضافه الى توفير الخدمات الترفيهيه والتجهيزات للسياحه النه 
وجاء في التزتيب الثالث العباره رقم (ץ*1/) وتنتبر الي ميزانيه مخصصـه من قبل الدوله لدعم

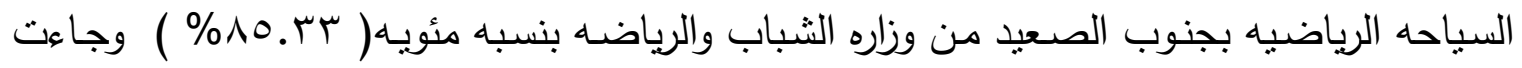

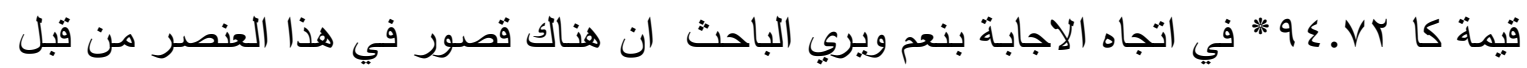
وزاره الثباب والرياضـه وضع ميزانيه مخصصسه للنهوض ودعم السياحه الرياضيه بجنوب الصعيد

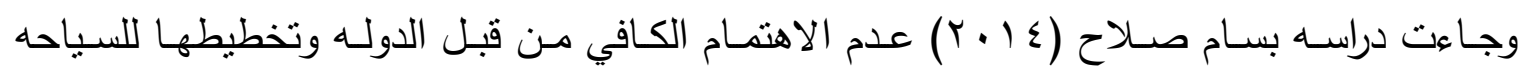
الرياضيه حيث وجد عدم وجود ميزانيه مخصصه من قبل الدوله لتطوير برامج السياحه الرياضيه

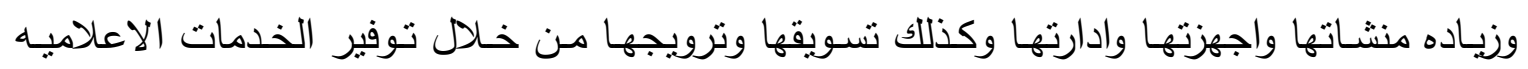

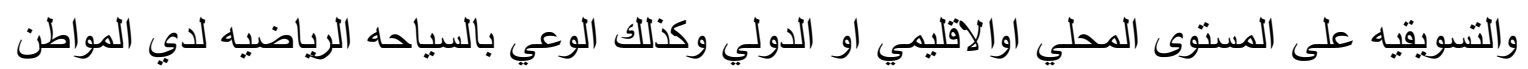

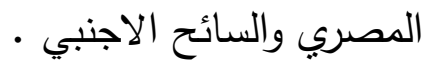

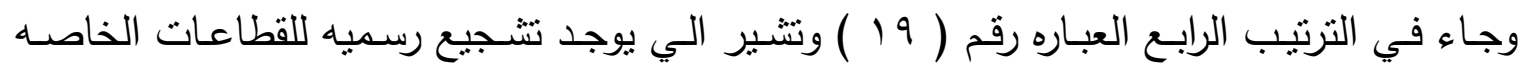

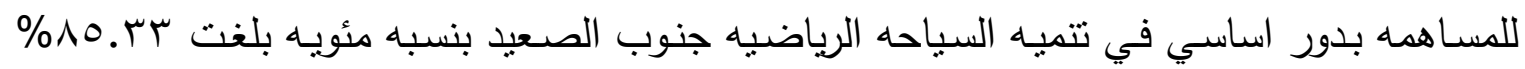

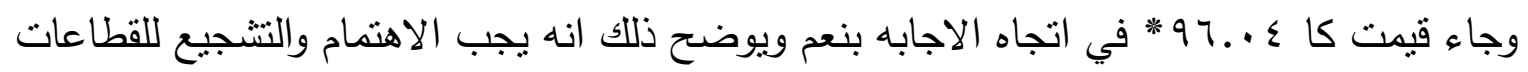
الخاصـه والاستتمار للمسـاهمه بدورها الاساسي في تتميه السياحه الرياضيه وكانت نتائج دراسـه

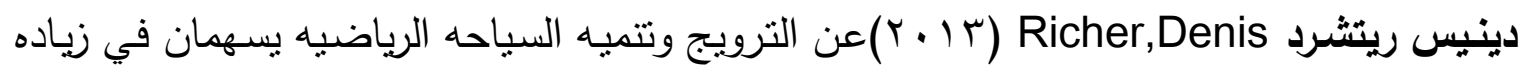
فرص العمل والدخل القومي وعمل تتميه وتحسين بالصحه والتعليم وايضـا دراسه ريشارد كوليمان

Richard Coleman

( ( • ( العلى النتيجه استضافه المسابقات والدوريات الرياضيه بالمدن الامريكيه يحدث اهتمام التتميه الاقتصاديه للمدن وتتميه منشاتها العامه والحيويه ويجب تتجيع القطاعات الخاصه على الاستتمار في السياحه الرياضيه بمدن امريكا السياحيه .

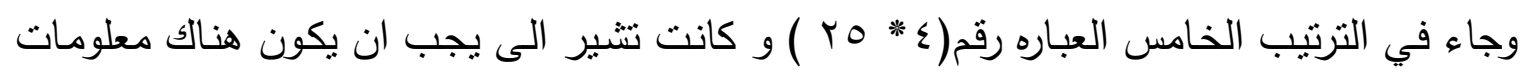

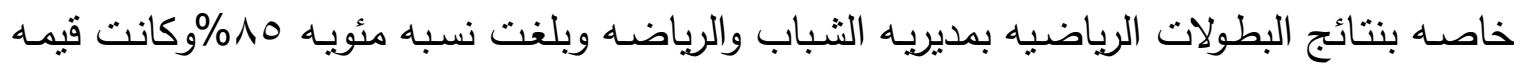

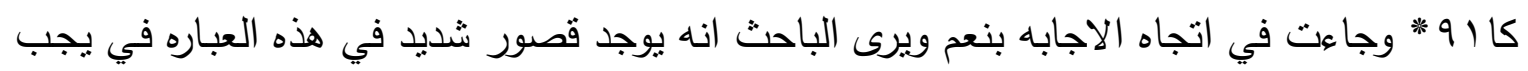

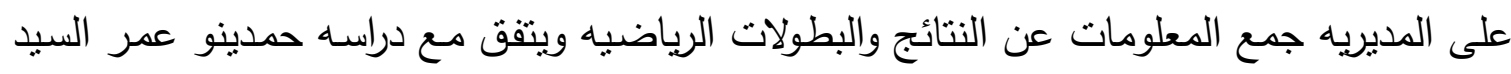

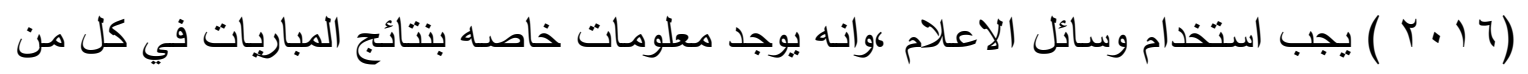

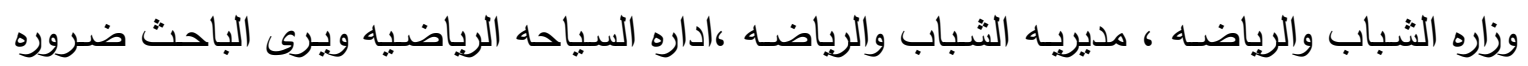

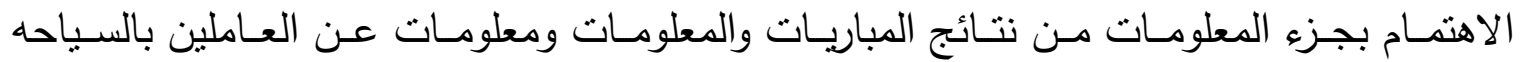

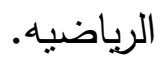

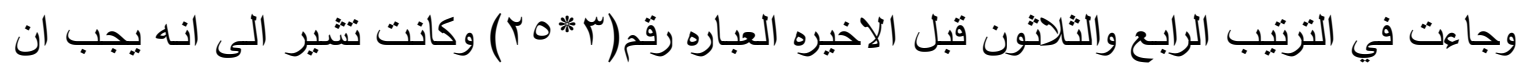

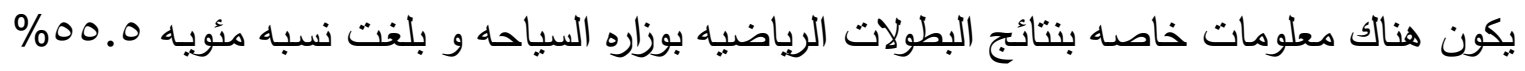




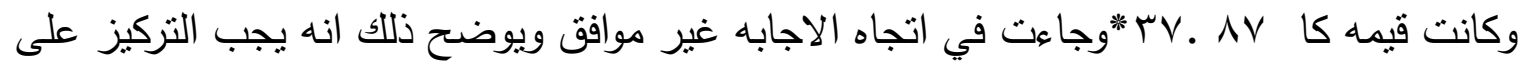
ان يوجد معلومات بالسياحه الرياضيه والبطولات و نسخه اخرى بوزاره السياحه.

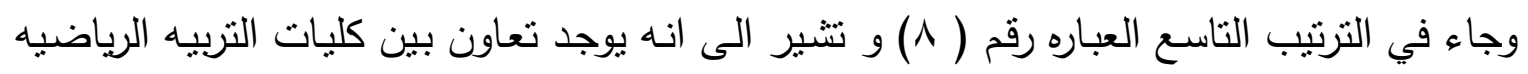

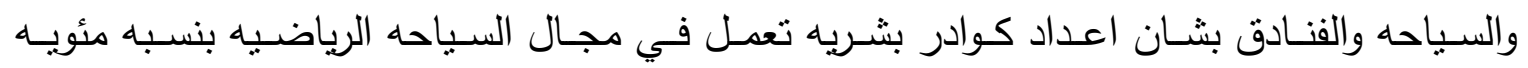

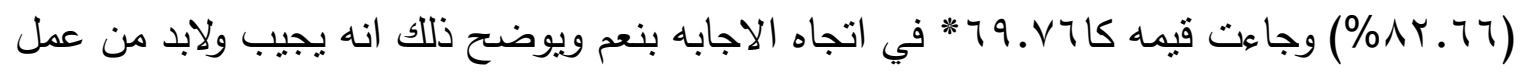

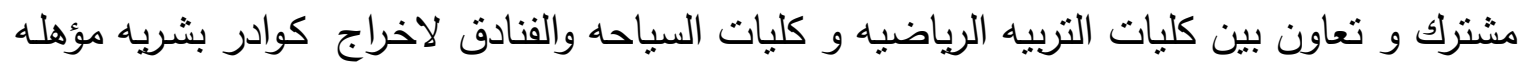

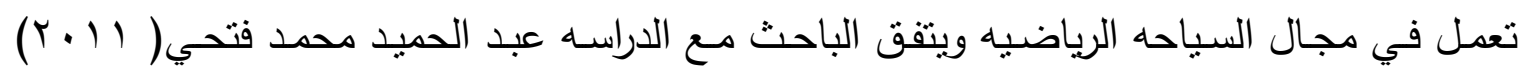

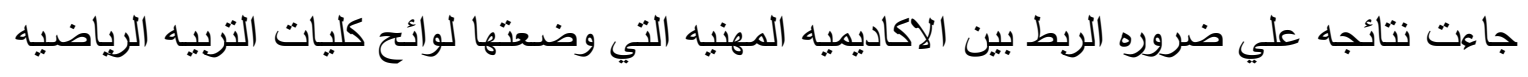

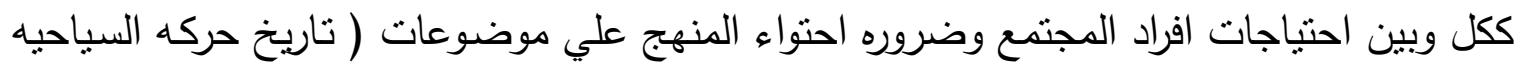

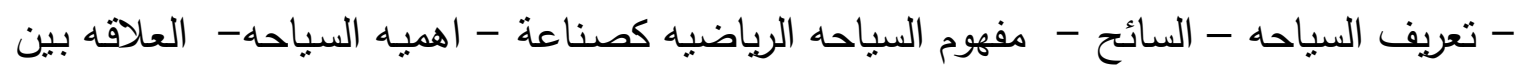

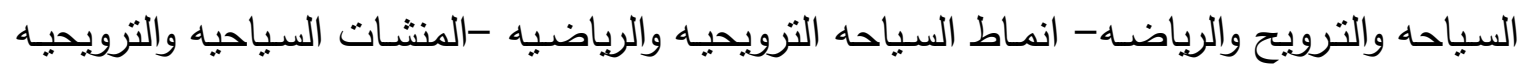

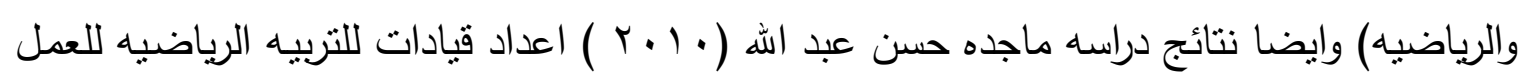

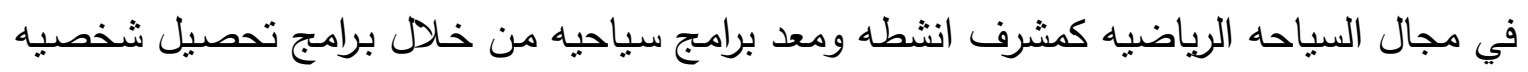

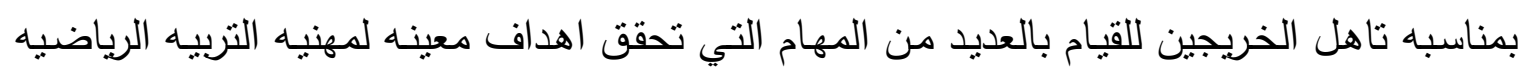

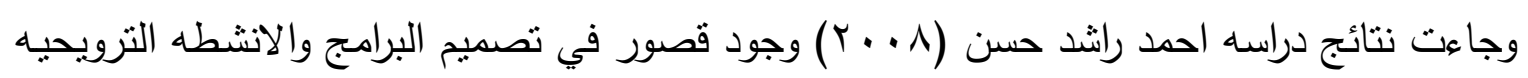
الحاليه بالقري والمنشات السياحيه لضعف اهدافها ووجود قصور في التاهيل الاكاديمي في العلم

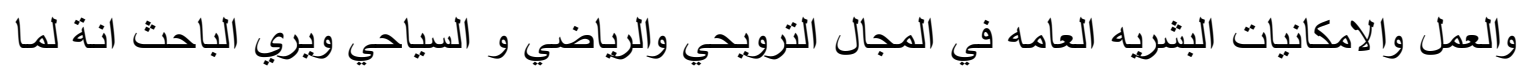

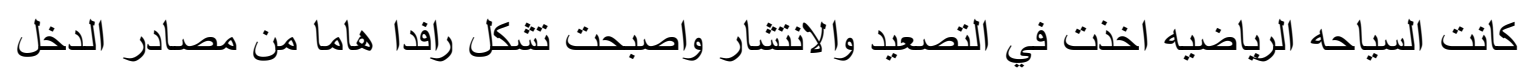

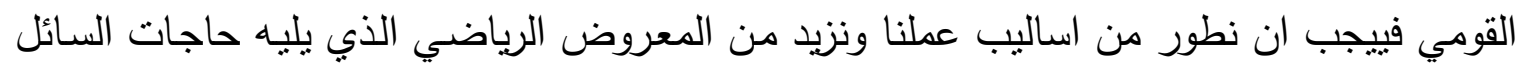
سواء الاوروبي او الاجنبي عموما وتهدف الى اعداد جيل من المتخصصين والمعدين اعدادا جيدا

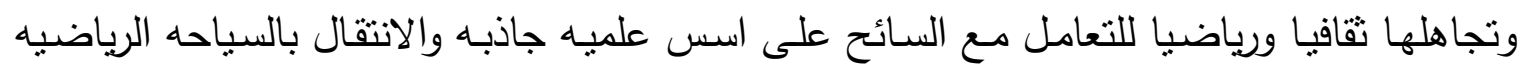

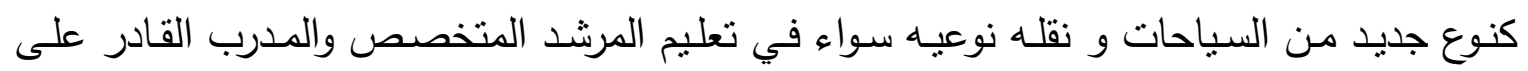

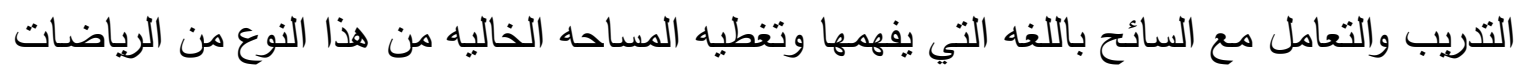
على مستوى الجمهوريه و عدم اقتصارها على البحر الاحمر فقط وانما تمتد لنتمل الصعيد والقاهره وبحيره ناصر والوادي الجديد وتطلع الى اضافه انشطه رياضيه جديده منل البرامج الرياضيه التاهيليه

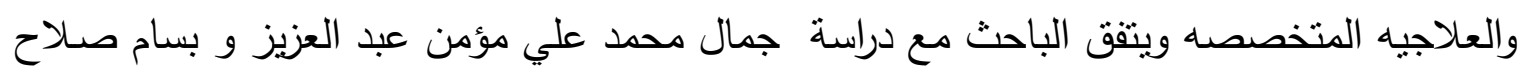

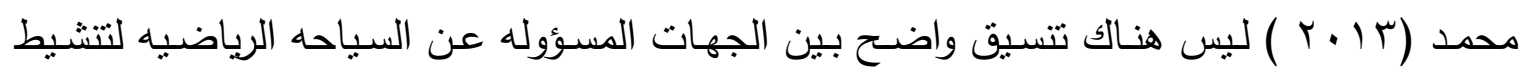

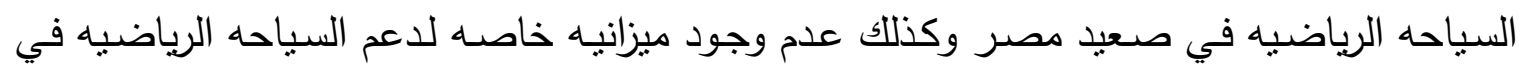

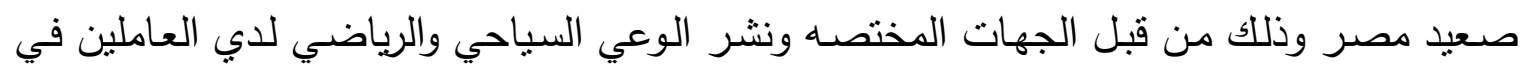


مجال السياحة الرياضية ويجب ارسال البعثات العلمية للدول المنقدمة في مجال السياحة الرياضية لتاهيل و اعداد الكوادر البشريه المتخصصه في مجال السياحه الرياضيه وكذللك عدم وجود خطه قوميه شامل لاعداد المتخصصين.

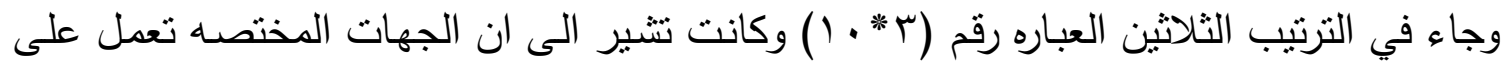
نثر الوعي بالسياحه الرياضيه لـاي العاملين بمجال الرياضي و مديريـه الثباب والرياضـه بنسبه

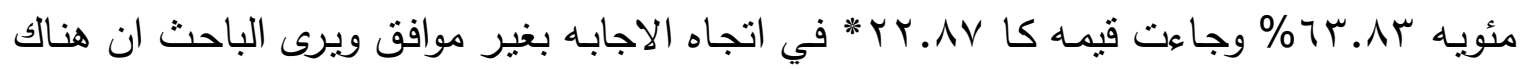
قصور في هذا العنصر فيجب الاهتمام والتركيز عليه وتاكد على ذلك دراسـه رانا محمود السيد

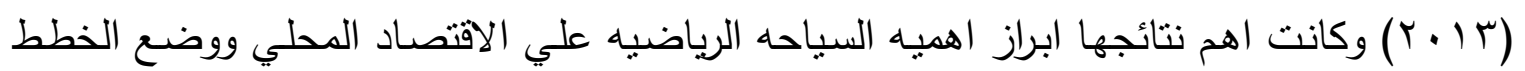

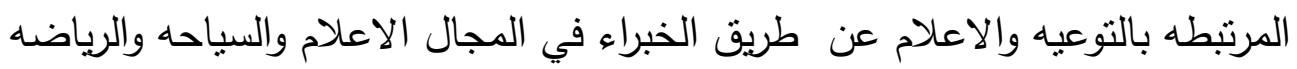

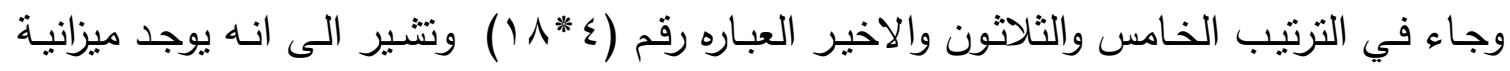
مخصصه من قبل الدوله لاعم السياحه الرياضيه بجنوب الصعيد من قبل الاتحادات الرياضيه بنسبه

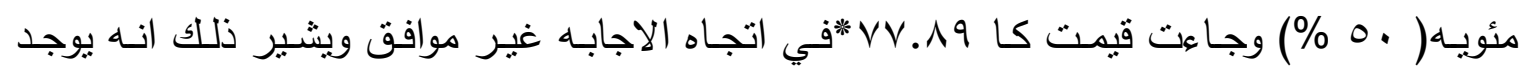
قصور في هذه العباره في هذا من خلال الدوله ومن خلال الاتحادات الرياضيه بالعكس لو اهتمت الاهت الاتحادات بالسياحه الرياضيه فانها تعمل على زياده الدخل و رفع الميزانيه لدي الاتحادات التهات الرياضيه

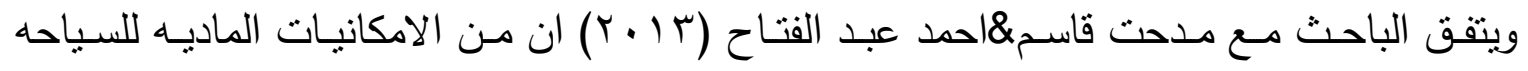

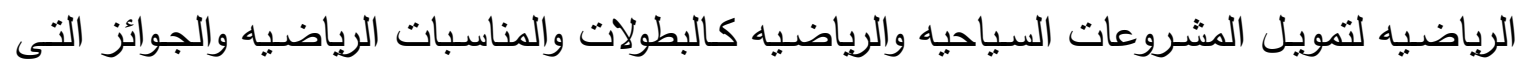

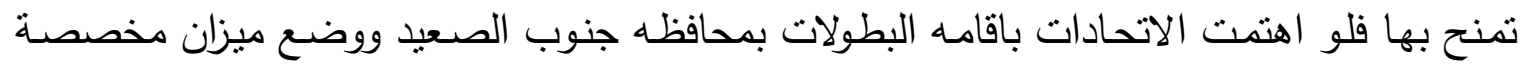

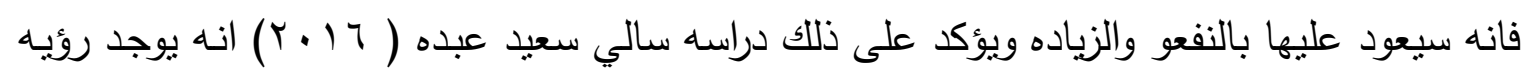
مستقبليه للسياحه الرياضيه في ضوء التحديات المعاصره من قبل الاتحادات الرياضيه وزاره الثباب والرياضه و وزاره السياحه.

وان اكثر موارد السياحة الرياضية المتوفرة فى جنوب الصعيد هى وسائل النقل (البرى - الجوى -

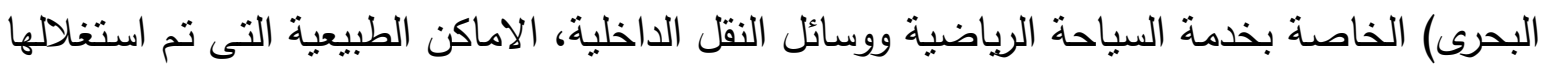

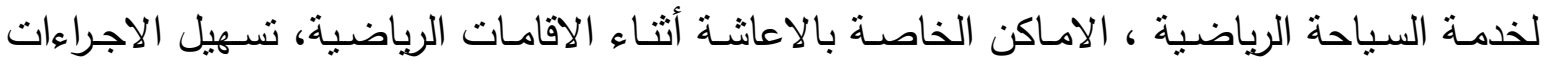

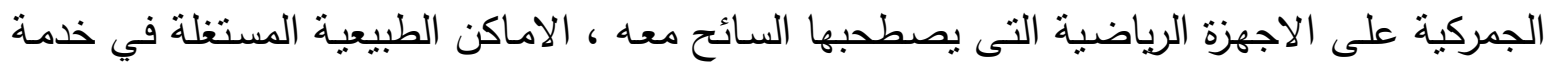

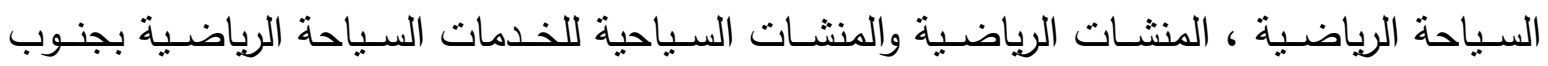
الصعيد.

بينما كانت اقل موارد السباحة الرياضية بجنوب الصعيد هي برامج التتشيط والتسويق فى مجال

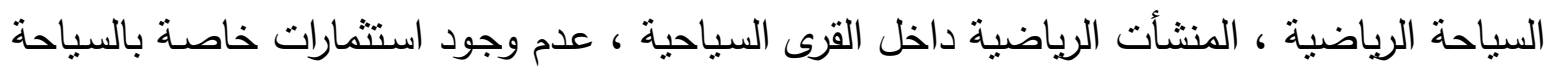

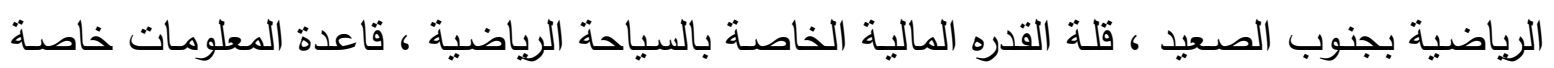


بالسياحة الرياضية ، التتوع فى البرامج الرياضية المقدمة للسائحين ، القيادات الرياضية المؤهلة للعمل فى مجال السياحة الرياضية ، الخدمات الطبية اثناء ممارسـة الانشطة الرياضية السياحية ، وهناك

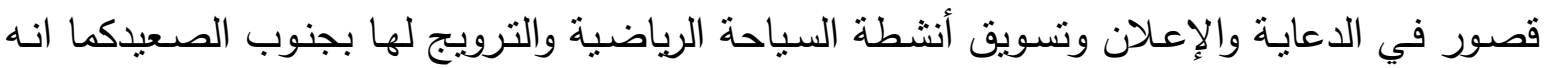

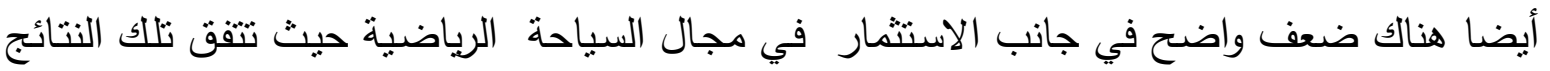

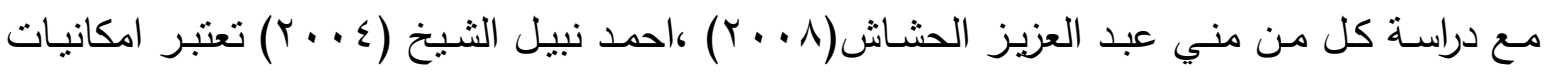

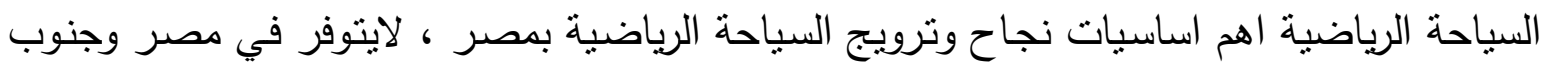
الصعيد الاخصائيون القادرون علي العمل في مجال السياحة الرياضية حيث لايتوفر بكليات التربية

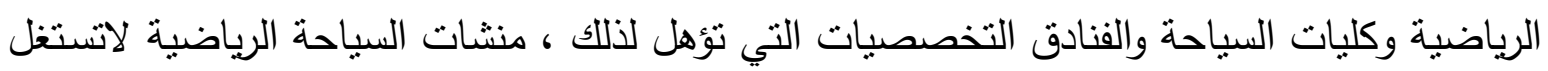

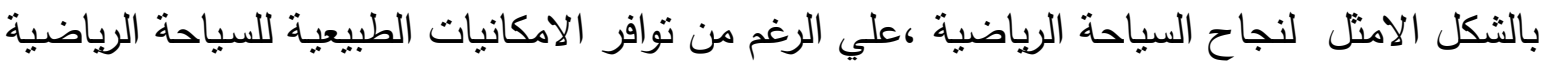

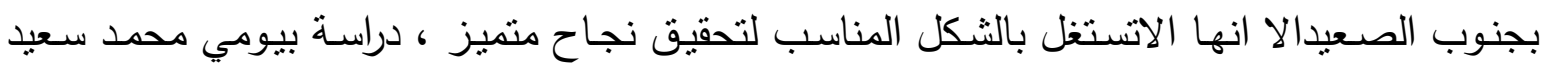

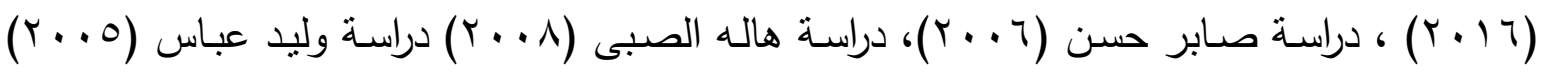

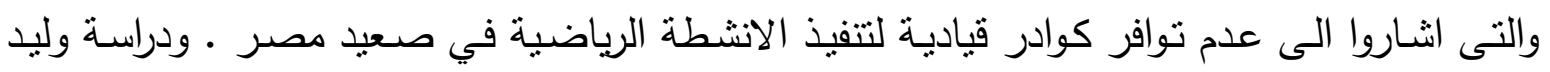

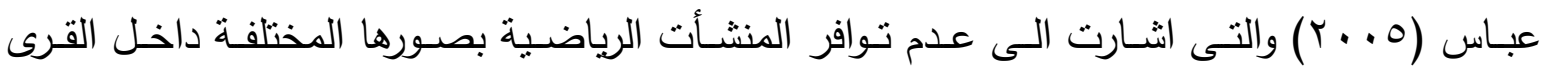

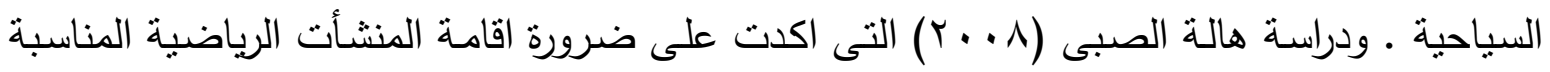

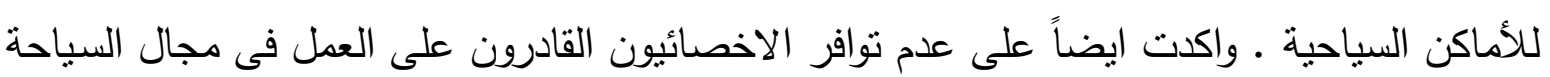

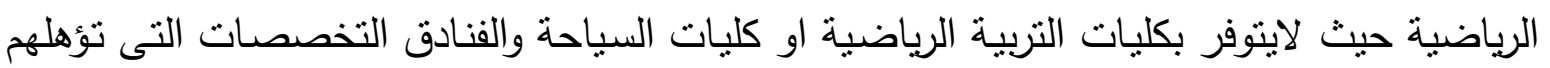
لذلك .

ويري الباحث ان يوجد اماكن طبعية وصحراوية وبحريه (نهر النيل) ومناخية وجزرلا نستغل الاستغلال

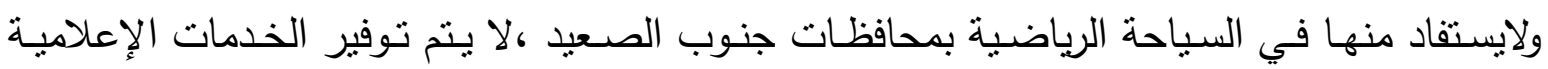
والتسويقية لدعم السياحة الرياضية فى جنوب الصعيد وترويجها على المستوى الدولي والمحلى،هنالك الإلى ضعف واضح في جانب الاستثمار في مجال السياحة الرياضية بجنوب الصعيد

\section{- - الاستخلاصات والاستنتاجات - - الات}

1- البعد الاول (الموارد المادية)

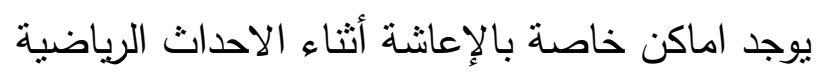
توجد منشات /ملاعب /صالات مغطاه/ وحمامات سباحة/ يمكن استغلالها لقيام السياحة الرياضية

r - البعد الثاني(الموارد البشرية ) توفير الكوادر البشرية المؤهلة للعمل في مجال السياحة الرئل الرياضية يجيد المشرفين الرياضيين التعامل مع مختلف ثقافات السائحين 
يتوافر فنيون صيانة الأدوات والأجهزة الرياضية بصورة كافية في أماكن ممارسة الأنشطة الرياضية السياحية

هناك تعاون بين كليات التربية الرياضية والسياحة والفنادق بشأن إعداد كوادر بشرية تعمل في مجال السياحة الرياضية

توجد هيئات استثمارية خاصة تساهم في تدريب كوادر بشرية للعمل في مجال السياحة الرياضية.

r- البعد الثالث(الموارد الطبيعية )

يعد التتوع النسبي لاثكال السطح بجنوب الصعيد عاملا مشجعا لقيام السياحة الرياضية بها.

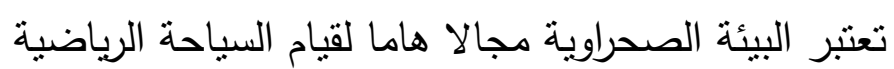

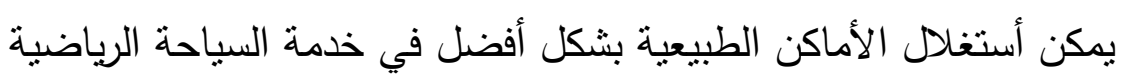
ع - البعد الرابع (الموارد المالية)

ميزانيـة مخصص مـن قبـل الدولـة لـدعم السياحة الرياضية بجنـوب الصـيد مـن قبل الاتحـادات

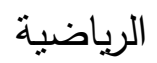
يوجد تشجيع رسمي للقطاع الخاص للمساهمة بدور اساسي في تتمية السياحة الرياضية بجنوب الصعيد ه- البعد الخامس (الموارد المعلوماتية) معلومات وقواعد بيانات لتسهيل اتخاذ القرار للمسؤولين عن السياحة الرياضية

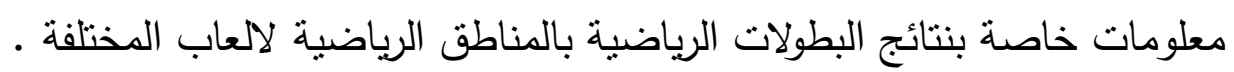

التوصيات من خلال نتائج واستخلاصات البحث يوصى الباحث - العمل على نشر الوعي بالسياحة الرياضية في جنوب الصعيد .

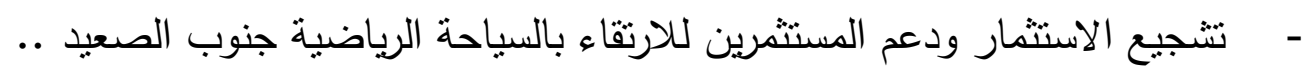
- - تتكيل إدارة للسياحة الرياضة بصعيد مصر وتحديد اختصاصاتها الوظيفية.

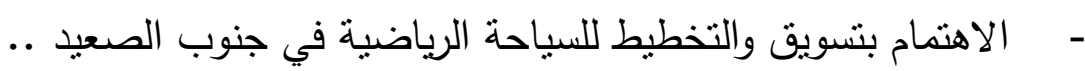
وضع خطة شاملة للإيفاء بمنطلبات السياحة الرياضية من إمكانات ومنشآت.

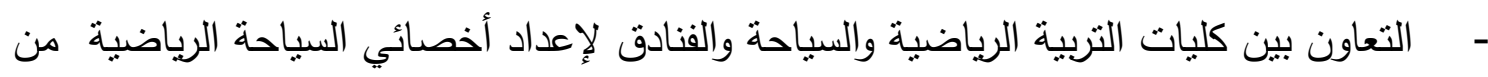
خلا إنشاء برامج دراسية وأقسام خاصة بإعداد كوادر بشرية للعمل في السياحة الرياضية. 
الاهتمام باسنضافة الأحداث الرياضية العالمية في محافظات جنوب الصعيد ـ ذات الطبيعية

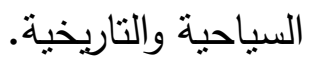
- تخطبط وإعداد برامج وأنشطة السياحة الرياضية بشكل منوازن ويتفق مع حاجات ورغبات المستفيدين بالاستتاد على الأسس العلمبة الصحيحة. - ت تقوم وزارة السياحة بالتعاون مع وزارة الثباب و الرياضـة بتوفير شبكة من المعلومـات تتشل على حصر دقيق وشامل على الاماكن التى تمارس فيها انثطة السياحة الرياضية بنوب الصعيد وذلك الكياب بالاستعانة بالخريطة المصمده العالمية . - وضع خطة إستراتيجية للنهوض بالسياحة الرياضية بجنوب الصعيد من قبل وزارة السياحة ووزارة

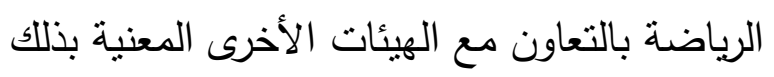

$$
\text { المراجـح }
$$

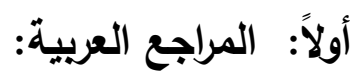

إبراهيم عبد المقصود ، حسن الثافعى (ع · . rم) : الموسوعة العلمية للإدارة الرياضية (العلاقات

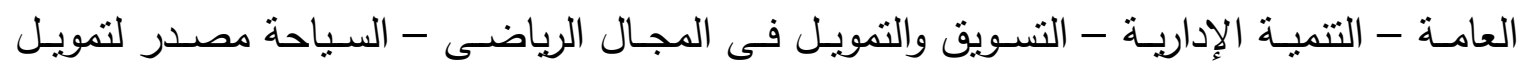
الرياضية) ، ط ا ، الإسكندرية ، دار الوفاء للنشر. أبويكر عونى عطية ( ؟ . . rم) : "التخطيط لموارد السياحة الرياضية لمحافظة الإسكندرية "، رسالة دكتوراة،غير منشورة ،كلية التربية الرياضية للبنات ،جامعة الإسكندرية. أحمد ســد الثـريف ( . . بم ) : على مسؤوليتهم السياحة والرياضـة "،مجلة الرياضـة والثباب،

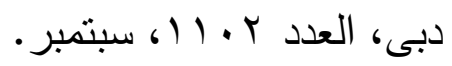
احمـد نبيل الثـيخ (ع ـ ـ بم) : " دور السياحة الرياضية في تتمية الموارد بالاتحادات الرياضية

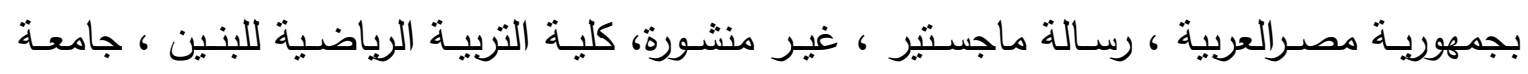
لزقازيق

أثرف سمير الميداني ( . . †م) : " تقويم إمكانات السياحة الرياضية في جمهورية مصر العربية"، رسالة ماجستير غير منشورة، جامعة الإسكندرية، كلية التربية الرياضية بابي قير ، الإسكندرية. اشرف صبحى محمد(ب . . rم) :" السياحة صناعة المستقبل، طنطا، دار الاسراء للنشر . 
بيومي محمد سعيد احمد (7 1 بم) : إستراتيجية مقترحة لتفعيل دور السياحة الرياضية بمحافظتى

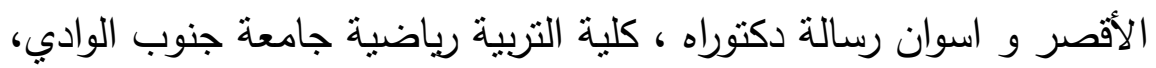

جمال محمد على، مؤمن عبد العزيز عبد الحميد، بسـام صـلاح محمد على (ب ا • بم): دراسة

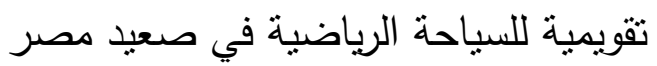

جمال محمد على،إبراهيم حسين إبراهيم، شيرين جلال شحاتة (11 +rم) : تصور مقترح لخريطة

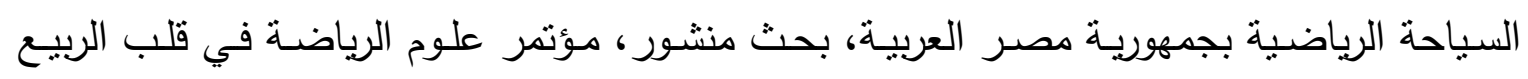

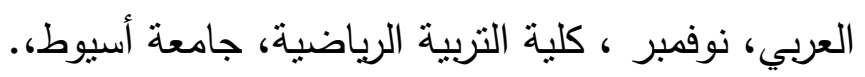

حمد ينو عمر السيد (11 + بم ) : دورالسياحة الرياضية فى مواجهة الازمة الاقتصـادية بجمهورية

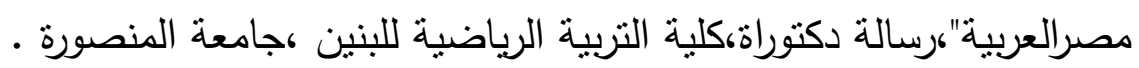

خالد محمد على عزب (ـ ( بم) : دراسة تحليلية للانشطة الترويحية المرتبطة بالألعاب الرياضية والمنتجعات السياحية بمدينة رأس سدر" ، رسالة ماجستير ، كلية التربية الرياضية للبنين، جامعة بنها لرئه عـادل طـاهر (r ( rم) : الرياضـة والسياحة" المجلس الدولي للتربية الرياضية والبدنية،السكرتاريا

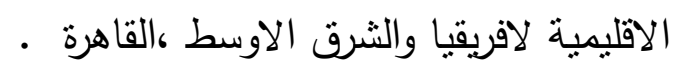

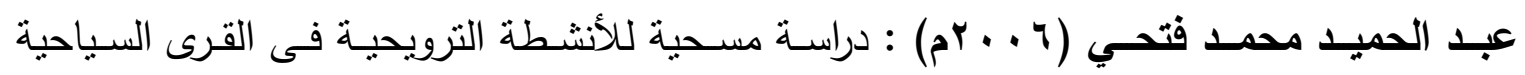
للحافظة البحر الاحمر ، رسـالة ماجستير ، غير منشورة، كلية التربية الرياضية للبنات، جامعـة

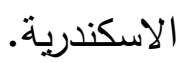

ماهر عبد الخالق السيسي (10 ب م) : مبادي السياحة الطبعة الثانية دار مجموعة النيل العربي

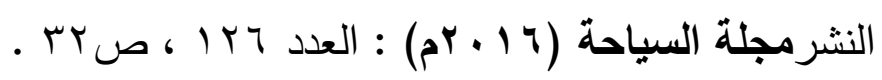

محمد أحمد خضرى (10 ·r) : نموذج مقترح لتفعيل مقومات السياحة الرياضية والعلاجية

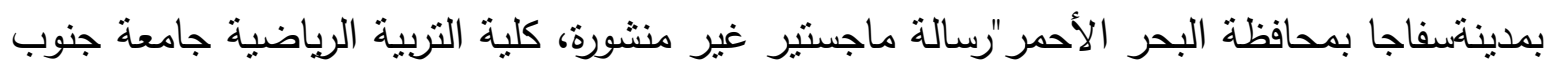
الوادى

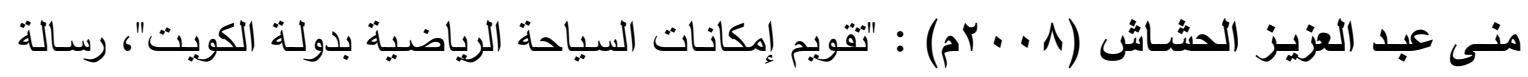
ماجستير غير منشورة ، كلية التربية الرياضية للبنات ، جامعة الاسكندرية .

مدحت قاسم ، احمد عبد الفتاح (ب ( + rم) : " السياحة الرياضية والمنتجعات الصحية العلاجية ،

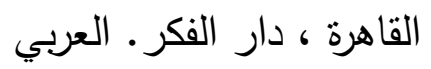




\section{المراجع الاجنبية}

David,A;Ghaily.y (2007) Modeling the demand for Australian domestic tourism, faculty of business and low, Edith Cowan university ,Perth،Australia.

Dong,H Zhouyan, Li (2010) The analysis of Conjugated in Fluential Factors onLeisureTourismDevelopmentinChina.

Freyer,W, (2014): Sporund Tourismus, Megamarkte In Der WissenSchaftlchen Disk ussion InTroslen,G.

Richard coleman (2010):" the hidden benefits of non-elite mass participation sports events : aneconomic perspective non -elite mass participation events hidden benefits cost effectiveness participation engagement ..

Ya - Huei Fan (2008):" An investigation of the interrelationships among a Taiwan sport tourism event image, destination image, and the participants intention to revisit a dissertationsubmitted to the Faculty of the united states sport Academy for the degree of Doctor of Education in sports Management, August 